\title{
DISMANTLING CIVIL RIGHTS: MULTIRACIAL RESISTANCE AND RECONSTRUCTION
}

\author{
ERIC K. YAMAMOTO, "SUSAN K. SERRANO, "* MiNAL SHAH \\ FENTON," JAMES GIFFORD," DAVID FORMAN," BILl HOSHIJO"* \\ AND JAYNA KIM ${ }^{* *}$
}

\section{PROLOGUE}

I am from Hawai'i, America's fiftieth state. I am a third generation Japanese-American. At the turn of the last century, my grandparents hoped to better their hard life in Japan and emigrated to work on Hawai'i's sugar plantations. In response to oppressive work and living conditions, my grandfather helped a fledging union fight the White plantation owners who controlled all the political and economic life in the territory. He was branded a trouble-maker and a traitor. He was forced to flee and change his family name.

* Professor of Law, William S. Richardson School of Law, University of Hawai' i. Co-authors Yamamoto, Serrano, Fenton and Gifford are co-founders of the Racial Justice Center. The Prologue, written in the first person, is authored by Professor Yamamoto. This personal account opened his presentation at the "Civil Rights in the New Decade" Symposium, sponsored by the Cumberland Law Review, the Cumberland School of Law, and the Birmingham Civil Rights Institute, on February 15, 2001.

* Thurgood Marshall Fellow, Lawyers' Committee for Civil Rights of the San Francisco Bay Area; J.D. 1998, William S. Richardson School of Law, University of Hawai'i.

"* Law Clerk, Hawai'i Supreme Court; J.D. 1998, Hastings College of the Law.

* Law Clerk to the Honorable Steven H. Levinson, Hawai'i Supreme Court; J.D. 1999. University of Arizona School of Law.

** Executive Director, Hawai'i Appleseed Public Interest Law Center; Associate, Alston Hunt Floyd \& Ing; Member, Hawai'i Advisory Committee to the United States Commission on Civil Rights.

** Executive Director, Hawai'i Civil Rights Commission; Co-founder, Na Lōio No Nā Kanaka - The Lawyers for the People of Hawai'i.

* Staff Attomey, Hawai'i Civil Rights Commission.; J.D. 1999, William S. Richardson School of Law, University of Hawai'i. 
At the same time, Hawai'i's indigenous peoples, Native Hawaiians, struggled for survival. They had their sovereign nation illegally overthrown with direct U.S. military support. They lost their homelands. Indeed, the U.S. took all Hawaiian government lands - one-third of all lands of the territory. Native Hawaiians had their language barred and customs denigrated and were characterized as uncivilized; and they were decimated by western disease. Hawai'i became largely populated by White Americans and immigrant workers of color. ${ }^{1}$

When I was eighteen, just learning about life, I went to a beautiful, isolated beach. Waimānalo is where many Native Hawaiians live on specially designated Hawaiian Homelands (in 1921 the U.S. returned some lands in trust for Native Hawaiians who were then seen as a "dying race"). ${ }^{2}$ Waimānalo is culturally rich and economically poor. As I walked, I met a Hawaiian elder, who looked cautiously at me and asked, "Why are you here?" She startled me. Was she asking if I was lost? Did she know I lived in a nearby town? Only later did I realize that she was really asking if $I$, as an American with Asian immigrant roots, understood what it meant to stand on native lands; did I understand the Hawaiian struggle to deal with the consequences of culture destruction and the loss of nationhood?

Since that time, wherever I go, I ask myself, "Why are you here?" Not because I am lost, but because of the importance of place and history to peoples' spirit, daily concerns and larger goals.

It is in this light, I say to you, I am honored to be here with the Birmingham Civil Rights Institute and Cumberland Law School to talk with you and mutually share learning. Birmingham has such a rich history of justice struggle. And in my

1 See generally TOM COFFMAN, A NATION WITHIN (1998); LILIKALA Kame`elehiwa, NATIVE LAND AND Foreign DESIRES - PEHEA LA E PONO AI? (1992).

2 In 1920, Prince Jonah Kuhio, the then-Territory's sole delegate to Congress, testified before the full U.S. House of Representatives that unless conditions improved the Hawaiian race would "pass from the face of the earth." 59 CONG. REC. 7453 (1920) (statement of Prince Jonah Kuhio Kalanian'ole). The Hawaiian Homes Commission Act of 1920, Pub. L. No. 76-34, 42 Stat. 108 (1921) was thereafter enacted in an effort to "rehabilitate" Native Hawaiians by returning them to their ancestral lands. See H.R. REP. No. 839, 66th Cong., at 3-4 (2d. Sess. 1920) (testimony of Senator John H. Wise of the Legislative Commission of the Territory of Hawai' $i$ to the House of Representatives). The promise of the Hawaiian Homelands, however, has been problematic, as the program from its inception has been plagued by a lack of resources, questionable transfers and exchanges of land, and a decades-long waiting list. See S. REP. No. 424, 106th Cong. (2d Sess. 2000). 
learning I honor the African Americans and their friends who struggled in the schools, workplaces, lunch counters, buses, and streets for civil rights so that all might benefit.

The conference organizers tell me also that I am here because my frontline and scholarly civil and human rights work, and the diverse civil rights work of this article's co-authors, crosses racial, geographic, and national boundaries. In our work toward justice, we engage the difficult task of trying to build bridges over the divides of race, citizenship status, gender, sexual orientation, age, and disability. Civil rights, we have come to see, start with African American justice and now also reach out like branches on a large tree to connect many others struggling for just treatment in America. ${ }^{3}$

With these experiences as a background, my presentation for the "Civil Rights in the New Decade Symposium" and this collaborative article focus on the pressing need for progressives to cross traditional boundaries of race, national origin, and citizenship and, additionally, gender, sexual orientation and disability and forge lasting alliances to combat the hugely successful, orchestrated twenty-year conservative assault on civil rights. Border-crossing and alliance-forging by "those committed to genuine equality," which is how we define "progressive," has always been difficult. Now, it is even harder, and

3 To make this more concrete, racially, we co-authors are Americans of Japanese, Filipino, Asian Indian, Korean, Puerto Rican, Caucasian, Hawaiian and Chinese ancestry. Our work includes serving on the legal team successfully reopening the infamous World War Il Japanese American Korematsu internment case, which fueled the reparations movement; serving as procedural consultant in the human rights class action on behalf of 10,000 torture and murder victims of the Ferdinand Marcos regime in the Philippines; serving as co-counsel on behalf of Hawaiian Homelands trust beneficiaries in their successful suit against the state; participation with a working group researching and advocating for African American reparations for slavery and Jim Crow segregation; establishing an immigrant rights center that primarily serves Asian and Pacific Island immigrants, with special emphasis on domestic violence; representing a Filipino American in his Title VII discrimination challenge; organizing students around voter initiatives; providing student legal services to Native Americans; serving on the legal team challenging racial discrimination in University admissions; organizing against the "Racial Privacy Initiative" in California designed to prevent the collection of race data; challenging unlawful INS arrest and deportation practices on behalf of immigrants; participating in redistricting efforts for African American communities; inaugurating a public interest educational and advocacy "Appleseed" program; orchestrating Asian American organizational support for Native Hawaiian sovereignty; defending Hawaiian Homelands Trust beneficiaries in suit to dismantle all government-supported Hawaiian programs; serving on advisory board to U.S Civil Rights Commission; testifying before the United Nations Commission on Human Rights regarding contemporary forms of racial discrimination in the United States; organizing against California's Proposition 209; organizing and training law students to represent immigrants and farm workers. 
more important, because of the largely anti-civil rights posture of the new presidential administration, with John Ashcroft's ascension to Attorney General and Theodore Olsen's appointment as Solicitor General.

This jointly written article is divided into two parts. The first section is a close look at the on-going conservative legalpolitical effort to dismantle civil rights-how it is being achieved piece by piece through the federal courts and state legislatures and voter initiatives and how this dismantling hurts all communities. The second section begins to address how progressive racial communities might build alliances among themselves and with White Americans committed to justice in the face of continuing civil rights retrenchment.

Eric K. Yamamoto

\section{INTRODUCTION: SANDOVAL AND THE ATTACK ON CIVIL RIGHTS}

During the 2000 presidential election, Americans awoke to a startling reality - the politics of law. Through the uproar, we glimpsed a legal world of Supreme Court decisions split along ideological lines.

This politics of law, which disenfranchised many African American voters, ${ }^{4}$ also drives the on-going attack on civil rights. During the past twenty years, Republican-appointed federal judges, supported by conservative think tanks and advocacy groups, have dismantled hard-earned civil rights for African Americans and other racial groups. ${ }^{5}$ That process has accelerated now in Alexander $v$. Sandoval, ${ }^{6}$ a case awaiting final

- See e.g., Florida Vote Prompts Demand for Investigation/Black Leaders Demand Answer to Florida Vote Questions, S.F. CHRON., Dec. 16, 2000, at A1 (reporting that many of the precincts affected by voting irregularities were predominantly Black).

5 See generally Angela Harris, Equality Trouble: Sameness and Difference in Twentieth-Century Race Law, 88 CAL L. REV. 1923 (2000); Frances L. Ansley, Stirring the Ashes: Race, Class and the Future of Civil Rights Scholarship, 74 CORNELL L. REV. 993 (1989); see JEAN Stefancic \& RichaRd Delgado, No MERCY: How Conservative Think Tanks AND FOUNDATIONS CHANGED AMERICA'S SOCIAL AGENDA 139-54 (1996).

6197 F.3d 484, reh'g en banc denied, 211 F.3d 133 (11th Cir.), cert. granted sub nom. Alexander v. Sandoval, 121 S. Ct. 28 (2000). The attack on civil rights enforcement intensifies with the proposed ballot initiative, dubbed by its proponents as the "Racial Privacy Initiative," amending the California Constitution to prohibit the state from collecting data on race, ethnicity, color, or national origin in the operation of public education, public contracting or public employment. Race, Ethicity, Color or National Origin Classification, Initiative for Constitutional Amendinent (cleared for petition circulation by California Attorney General April 2001). Under the mantle of "colorblindness," this initiative would prohibit the state from gathering data needed to enforce 
decision by the United States Supreme Court.

Sandoval is significant because it involves the Alabama government's quiet attempt to knock out a cornerstone of the 1960 s' $^{\prime}$ civil rights edifice. More specifically, the case threatens the basic right of individual victims to sue under Title VI of the 1964 Civil Rights Act to ensure that federal dollars do not subsidize "disparate impact" discrimination by states or private businesses.?

The facts of Sandoval are deceptively simple. Partly in response to an increasing Latino population, Alabama voters amended the state constitution to establish English as the "official language of the State of Alabama." 8 The amendment required the Alabama legislature to "take all steps necessary" to preserve and enhance the role of English as the common language of the State. ${ }^{9}$ The Motor Vehicles Department then stopped its decade-long practice of administering driver's license exams in fourteen languages and gave its tests in English only, effectively disqualifying limited proficiency English readers, including those capable of reading street signs. ${ }^{10}$ The state justified English-only testing on grounds of safety, even though there had been no safety problems under the past multilingual system and even though the department allowed foreign li-

civil rights, monitor discrimination and hate crimes, address the unique healthcare and educational needs of different communities, and conduct meaningful studies on the effectiveness of anti-discrimination laws and other efforts to provide equal opportunity and ensure diversity.

7 See infra note 121-25 and accompanying text (describing "disparate impact" discrimination and its legal treatment). Title VI of the Civil Rights Act of 1964 prohibits discrimination based on race, color or national origin by federally funded entities. 42 U.S.C. $\$ 2000 d$ et seq. (1994). Congressional authority for Title VI is derived from the Constitution's Spending Clause. U.S. CONST. art. I, \$ 8. Title VI contains two separate sections that provide different enforcement mechanisms. See 42 U.S.C. \$ $2000 \mathrm{~d}$ et seq. Under section 601 of Title VI, private citizens may file a private lawsuit challenging the discriminatory actions of any recipient of federal funds. See Alexander v. Choate, 469 U.S. 287, 293-94 (1985). In a plurality opinion, the Supreme Court imposed a high standard of proof under section 601 by requiring a plaintiff to demonstrate that the recipient has consciously discriminated against minority groups. See Guardians Ass'n v. Civil Service Comm'n, 463 U.S. 582 (1983). Under section 602 of Title VI, the Supreme Court has held that agencies have the authority to promulgate regulations that prohibit recipients of federal funds from taking any action that results in a disparate impact or produces discriminatory effects on the basis of race, color or national origin. See id.; see also Alexander, 469 U.S. at 293 . The central issue presented in Sandoval is whether there is an implied private right of action for disparate impact cases based on regulations promulgated under section 602 . Sandoval v. Alexander, 197 F.3d 484, 502 (11 th Cir. 2000).

8 Id. at 488 (citing ALA. CONST. amend. 509)

9 Id.

10 Id. at $487-88$. 
censed and non-literate people, among others, to drive.11

Martha Sandoval sued in federal court alleging, inter alia, that the departmental policy discriminated against her and others similarly situated on the basis of national origin in violation of Title VI of the Civil Rights Act of 1964 and its implementing regulations. ${ }^{12}$ More particularly, she alleged that the department's policy and practice, in its effect, discriminated against limited English reading immigrants. The district court and United States Court of Appeals for the Eleventh Circuit validated her Title VI discrimination claim. ${ }^{13}$ On appeal to the United States Supreme Court, Alabama did not contend that its English-only testing was non-discriminatory. ${ }^{14}$ Rather, it argued that Title VI does not create a private right of action against states (or private businesses) for "disparate-impact" violations - that is, all victims of discrimination, citizens and non-citizens alike, should be denied access to courts to enforce federal agency anti-discrimination regulations. ${ }^{15}$

On its facts, Sandoval is about the needs of newcomer Americans to be free from national origin discrimination that deprives them of the basic tools for social and economic survival. ${ }^{16}$ While specifically dealing with drivers' licensing, a

1 Id. at 488,490 . Although the Department's policy prohibited use of interpreters, translation dictionaries, and other interpretive aids, it provided "special accommodations for illiterate, hearing-impaired, deaf, and disabled applicants." It also allowed "[n]on-English-speaking drivers from other states and foreign countries to exchange a valid out-of-state license for an Alabama license without taking the written exam." Id. at 488.

12 ld. at 487 . The regulations at issue provide that a funding recipient may not, directly or through contractual or other arrangement, utilize criteria or other methods of administration which have the effect of subjecting persons to discrimination because of their race, color or national origin, or have the effect of defeating or substantially impairing accomplishment of the objectives of the program with respect to individuals of a particular race, color or national origin.

Id. at 502 (citing 49 C.F.R. $\$ 21.5$ (b)(2) (Department of Transportation)); 28 C.F.R. $\S$ 42.104(b)(2) (Department of Justice).

13 The district court enjoined the Department from enforcing the English-only policy and directed it to implement accommodation for Alabama's non-Englishspeaking residents. Sandoval, 197 F.3d at 489. The United States Supreme Court granted certiorari to review the decision of the Eleventh Circuit on September 26, 2000. Alexander v. Sandoval, 121 S. Ct. 28 (September 26, 2000) (mem.).

if Petitioner's Brief, 1999 U.S. Briefs 1908 at *20, Alexander v. Sandoval, 121 S. Ct. 28 (November 13, 2000).

15 Id.

16 Respondent's Brief at *3 n.2, Alexander v. Sandoval, 121 S. Ct. 28 (2000) ("the denial of driver's licenses to such immigrants actually 'retards the learning of English' and 'jeopardizes the assimilation of limited and non-English speaking persons into the community' by tending to cut them off from 'normal interactions with English speakers in the community at large.'”) (Sandoval v. Alexander, 7 F. Supp.2d 1234 
"no-individual-right-of-action" ruling will also extend to all manner of newcomer discrimination by states and private entities receiving federal funds.

Sandoval is also significant because of its sweeping reach. It raises the crucial question of who, in practice, will sue to end illegal discrimination by many entities receiving federal money. If harmed individuals are barred from the courthouse, and enforcement of federal agency non-discrimination mandates is left to overburdened or uninterested agencies under Attorney General Ashcroft's command, then exceedingly few worthy disparate impact challenges will be initiated. ${ }^{17}$ Vindication of civil rights, including newly emerging environmental racism/justice claims under Title VI, ${ }^{18}$ will lag as states and private entities face sharply diminished prospects of legal sanctions for violating federal agency anti-discrimination rules.

Finally, placed in legal historical context, Sandoval is significant because it signals another pivotal retreat from America's commitment to civil rights for all, and particularly for those suffering most from historic forms of discrimination. ${ }^{19}$ Piece by piece, a divided Supreme Court has dismantled civil rights. As developed below, the Court has been doing so under the Fourteenth and Fifteenth Amendments by banning claims of institutional discrimination, invalidating affirmative action programs, limiting federal court powers to monitor school desegregation, rejecting proof of racially discriminatory impact in deathpenalty sentencing, countermanding state voter redistricting designed to ensure that votes of minorities count, invalidating disability rights legislation, and striking down state constitu-

(M.D. Ala. 1998)); see also Sandoval, 197 F.3d at 489-90 ("thousands of Alabama residents of foreign descent suffer adversely from the Department's English-only policy ... not having a license often affected the ability of these adults to obtain employment, child care services, and other life essentials.") (quoting Sandoval, 7 F. Supp. 2d 1234).

17 Id. at *29-30 (highlighting the enforcement difficulties in compelling agencies to investigate claims and discontinue funding).

18 See Julia B. Latham Worsham, Disparate Inpact Lawsuits Under Title VI, Section 602: Can a Legal Tool Build Enoironmental Justice?, 27 B.C. ENVTL. AfF. L. ReV. 631 (2000) (arguing for use of Title VI, Section 602 as basis for environmental racism/justice claims that combine traditional environment law with civil rights); see also Richard J. Lazarus, Pursuing "Environmental Justice": The Distributional Effects of Environmental Protection, 87 NW. U. L. REV. 787 (1993) (discussing racial and economic inequities in the distribution of the benefits and burdens of environmental protection and proposing Title VI civil rights claims as a possible basis for redress); Eric K. Yamamoto and Jen-L Wong, Racializing Environmental Justice, U. COLO. L. REV. (forthcoming 2001).

${ }_{19}$ See infra Section I.A and B (discussing First and Second Reconstruction). 
tional provisions that provide Native Hawaiian elections as a measure of self-determination. ${ }^{20}$

The Court also has been dismantling civil rights through the Eleventh Amendment, the Commerce Clause, and the movable mantle of "states' rights," deferring to states when they cut back on civil rights and overruling states when they expand civil rights protections. For instance, it has narrowly redefined the reach of the Constitution's Commerce Clause to block a Congressional act civilly advancing women's rights to be free from violence and to invalidate key parts of age discrimination legislation. ${ }^{21}$ The Court has also been narrowly interpreting the employment discrimination remedies of Title VII of the Civil Rights Act. ${ }^{22}$ And now the Court is poised, through Sandoval, to allow any state to take a step back in the direction of Jim Crow America. Indeed, a Court ruling invalidating private rights of action to enforce federal agency disparate impact regulations will accelerate the law's movement toward increasing legal acceptance of discrimination against America's communities of color.

How is this systematic, multifaceted attack on civil rights being achieved? How is it harming the long-term social health of American society?

As developed in detail below, the United States promised real equality to African Americans following the Civil War in a period called the First Reconstruction. Newly freed African Americans began to make real political and economic gains. The federal government, however, quickly revoked that promise. The civil rights laws adopted as the foundation of the Reconstruction were torn apart by court rulings, massive political resistance, and a lack of public will. Segregation and other forms of discrimination, backed by threat of violence, took root in law and social practice. ${ }^{23}$

In the 1960s, the United States acknowledged its failed first promise of Reconstruction. After sustained African American protests against segregation, once again, the nation committed itself to equality and justice through both new laws and reinvigorated older ones (including the Fourteenth Amendment

20 tion).

${ }_{21}$ See infra Section I.C.2 (discussing indirect challenges to federal authority over states).

22 See infra Section I.C.1.b (discussing attacks on Title VII).

23 See infra Section I.A. (discussing the demise of the First Reconstruction). 
and 42 U.S.C. $\S 1983$ ) that, for a time, the courts vigorously enforced. The new laws included Title VII (employment), Title VI (federal contractors), Title II (public accommodations) and Title IX (gender) of the 1964 Civil Rights Act, the 1965 Voting Rights Act, and the 1968 Fair Housing Act. These new laws also supported affirmative action in order to begin to level a grossly unequal playing field. A Second Reconstruction, and real progress for African Americans, began to take hold. 24

But then, as before, came a cultural and political backlash against the gains by minorities, women, and immigrants, followed by the tide of court decisions dismantling civil rights. The civil rights retreat is now pushing the United States back toward a more divided society. Some call it the "resegregating" of America. Sandoval emerges in this setting.

To more fully illuminate the significance of Sandoval and the importance of collective multiracial responses to the attacks on civil rights, we locate the case in the context of America's historic civil rights struggle over racial equality. We also connect the legal dismantling of the post-Civil War First Reconstruction with the on-going conservative attacks on civil rights during the contemporary Second Reconstruction.

\section{BREAKING AMERICA'S CIVIL RIGHTS PROMISES: THE FIRST AND SECOND RECONSTRUCTIONS}

America's First Broken Civil Rights Promise was its legal dismantling of the First Reconstruction following the Civil War. ${ }^{25}$ The First Reconstruction, with its congressional civil

24 See infra note 87, and accompanying text.

25 The history of the relationship between the federal and state governments and Native Americans and their tribes is also marked by broken promises. Indeed, one government official declared in $\mathbf{1 8 6 9}$ that "[ $\mathrm{t}$ ] he history of the government connections with the Indians is a shameful record of broken treaties and unfulfilled promises." Report of the Board of Indian Commissioners, reprinted in DOCUMENTS OF UNITED STATES INDIAN POLICY 131 (Francis Paul Prucha ed., 2d ed. 1990) (1869); see also, ROBERT A. WILliaMs, JR., THE AMERICAN INDIAN IN WESTERN LEGAL THOUGHT (1990) (documenting the pattern of broken treaties and promises in the relationship between western European nations and the United States with Native Americans); Siegfried Wiessner, American Indian Treaties and Modern International Law, 7 ST. THOMAS L. REV. 567 (1995) (discussing America's history of breaking treaties and promises to Native Americans); Charles F. Wilkinson and John M. Volkman, Judicial Review of Indian Treaty Abrogation: "As Long as Water Flows, or Grass Grows Upon the Earth" - How Long a Time Is That?, 63 CAL. L. REV. 601 (1975) (discussing Congress' power to unilaterally abrogate treaties made with Indian tribes and noting that legal recognition of abrogation results in the destruction of treaty rights); Robert Yazzie, "Hozho Nahasdlii" - We Are Now In Good Relations; Navajo Restorative Justice, 9 ST. THOMAS L. REV, 117 (1996) (discussing Congress' failure to "keep its promises to combat modern social problems in Indian coun- 
rights laws and constitutional amendments, uplifted freed slaves, but only for a brief moment. That Reconstruction was dismantled by a combination of factors: by popular White backlash, by lack of presidential and congressional will (for example, the 1872 Hayes-Tilden presidential compromise in which the Republicans agreed to withdraw federal troops from the South), ${ }^{26}$ and by the imprimatur of Supreme Court decisions. Ruling by ruling, the Court gutted explicit civil rights protections for Blacks. The Court's methodology first defined civil rights laws in the narrowest possible fashion. It then refused to recognize other civil rights at all. Finally, when it did acknowledge African American rights, such as the right to vote, and found those rights violated by states, it declined to enforce them. Perhaps most significant, the Court signaled that it would abdicate authority over civil rights to the states, which created disastrous results. ${ }^{27}$

The Court, in concert with intractable White resistance, ${ }^{28}$ ushered in state law regimes of de jure Jim Crow segregation and contributed to the rise of the Ku Klux Klan and unchecked racial violence. The result: post- Civil War Reconstruction laws on the books but without enforcement, and continuing systemic subordination of African Americans. This meant exclusion from schools, workplaces, housing, social services, and politics, as well as the badge of racial inferiority. For African Americans, there was no steady post-Civil War upward pull toward equality. ${ }^{29}$ Indeed, the briefest bright moment of Reconstruction gave way to eighty years of social, economic, and political darkness - America's First Broken Civil Rights Promise.

African Americans continued their struggle for equality and justice in the face of state-sanctioned White terrorism and seg-

try"). For general histories of America's relationship with Native Americans, see generally DeE Brown, Bury MY Heart at WOUNDEd KNeE (1970); ANGIE Debo, A HISTORY OF THE INDIANS OF THE UNITED STATES (1970); VINE DELORIA, JR., AMERICAN INDIAN POLICY IN THE TWENTIETH CENTURY (1985). For an overview of America's relationship with Native Hawaiians, see generally KAME`ELEIHIWA, supra note 1; HAUNANIKaY TRASK, FROM A NATIVE DAUGHTER: COLONIALISM AND SOVEREIGNTY IN HAWAII (1993); LaWrence H. FuChS, HaWAil PONO: AN ETHNiC AND POlTICAL History (1961). 2000).

See generally DERRICK BELl, RACE, RACISM AND AMERICAN LAW 54 (4th ed.

27 See infra Section I.A.

28 See infra notes 50-53, and accompanying text.

29 BELL, supra note 26 , at 58 . 
regation. ${ }^{30}$ These struggles set the stage for the Civil Rights Movement and the Second Reconstruction. After organized and sustained protests and brutal government repression, which were carried into middle America by television, the United States renewed its commitment to civil rights and offered a hard-earned promise to African Americans and all subordinated Americans: real equality and justice-America's second Civil Rights Promise. This time, through the Second Reconstruction, America would do it right. Indeed, the Bull Connor fire hoses and attack dogs are gone, as are the "Whites only" signs in restaurants. Additionally, with the boost from the early stages of civil rights enforcement and affirmative action, a small Black middle class emerged and America's immigration laws opened doors to a more ethnically and culturally diverse populace. ${ }^{31}$

But large racial disparities persist. Comprehensive studies show continuing institutional discrimination against African Americans and other non-White racial groups. ${ }^{32}$ The United States has never actually leveled the steeply tilted racial playing field. Yet, as discussed below, America, again, through its courts, is revoking its commitment to the Second Reconstruction. And, as in its divisive past, it is doing so through piece by piece legal acceptance of discrimination.

Over the past twenty years, the progress of the Second Reconstruction and the substantial steps toward justice and equality have been reversed by increasing legal acceptance of inequality in America. 33 "Civil rights retrenchment" has been marked by successful direct challenges to federal civil rights legislation and constitutional protections, and by indirect challenges to federal authority over the states-the old states' rights argument dressed in new clothes. ${ }^{34}$

30 While organized racism in the early twentieth century took on a new nativist cast, it retained its old-style precepts of White supremacy:

[T]he new Invisible Empire expanded its sights beyond the old goal of keeping African Americans down ... [however,] the new KKK's activities in this regard were exemplary-Klansmen paraded through southern towns on the eve of the 1920 election to terrorize black people out of voting, intimidated black workers and pressured white employers to fire or demote them, and forced black people out of a part of South Jacksonville that white people wanted for themselves alone, to name a few examples[.]

See Harris, supra note 5, at 1974-75.

31 See infra notes 86-97, and accompanying text.

32 See infra notes 88-95, and accompanying text.

33 See infra Section II.C.

${ }^{34}$ See Kimberle Williams Crenshaw, Race, Reform, and Retrenchment: Transforma- 
Sandoval's likely elimination of a private right of action to enforce agency disparate impact regulations under section 602 of Title VI should be seen in this context-at the precipice of America's Second Broken Civil Rights Promise. The next section describes the specifics of civil rights retrenchment-the legal dismantling of the First and now the Second Reconstructions.

\section{A. The Demise of the First Reconstruction}

In the wake of the Civil War, the First Reconstruction provided a foundation for universal civil and political freedom throughout the United States. ${ }^{35}$ The Civil Rights Acts and the Thirteenth, Fourteenth, and Fifteenth Amendments to the United States Constitution were the centerpieces of a Reconstruction whose clear legislative and popular purpose was to uplift Blacks from two hundred years of systemic subordination in America. ${ }^{36}$ The Thirteenth Amendment ended slavery. ${ }^{37}$ The Fourteenth and Fifteenth Amendments were designed to end doubt about the constitutionality and purpose of civil rights laws. ${ }^{38} \mathrm{~A}$ series of Civil Rights Acts protected Black civil rights against state and private interference. ${ }^{39}$ In short, the evil

tion and Legitimation in Antidiscrimination Law, 101 HARV. L. REV. 1331 (1988) (describing the Reagan administration's hostility toward civil rights enforcement); see also infra Section II.C.

35 See generally ERIC FONER, RECONSTRUCTION: AMERICA'S UNFINISHED REVOLUTION 1863-77 (1st ed. 1989).

36 See Harris, supra note 5, at 1930-37 (describing the legal structure and subsequent dismantling of the First Reconstruction as historical context for the thesis that a constant tension in American race law has been the effort to reconcile constitutional and statutory norms of equality with the desire for White dominance).

37 U.S. CONST. amend. XIII, § 1 (“Neither slavery nor involuntary servitude, except as punishment for crime whereof the party shall have been duly convicted, shall exist within the United States, or any place subject to their jurisdiction."). Section 2 gave Congress the power to enforce this article through appropriate legislation. Id.

38 U.S. CONST. amend. XIV, $\S 1$ (nationalizing citizenship and prohibiting the states from abridging the privileges and immunities of any United States citizen or depriving any citizen of due process or equal protection under the law); U.S. CONST. amend. XV (guaranteeing the right to vote to all men regardless of race or color); see also Harris, supra note 5, at 1931-32.

39 See id. at 1932 (discussing a series of civil rights acts including, inter alia, the Civil Rights Act of 1866 (providing that all persons born in the U.S. were citizens, regardless of color, with the same rights as White citizens); the Civil Rights Act of 1870 (including all persons, rather than just citizens, within the jurisdiction of the U.S. and rendering illegal certain types of discrimination against Chinese); the Klu Klux Klan Act of 1871 (criminalizing conspiracy to deprive any person of equal protection); the Civil Rights Act of 1875 (requiring various places of public accommodation to, inter alia, open their accommodations to "all persons within the jurisdiction of the United States" subject to "conditions applicable alike to citizens of every race and 
addressed by these enactments was White supremacy.

For a brief period, the First Reconstruction contributed to relatively substantial gains in the African American community: school enrollment (two percent in 1860 vs. thirty-four percent in 1880); literacy rates (ten percent in $1860 \mathrm{vs.} \mathrm{thirty} \mathrm{per-}$ cent in 1880); land ownership (zero in 1865 vs. twenty percent in 1880); and political participation (zero Black public officials in 1867 vs. at least fifteen percent of all Southern officeholders by 1870 - and less than three percent in 1979)..$^{40}$ However, the promises provided by these civil rights laws and constitutional amendments were soon undermined by a combination of factors. Each branch of government-judicial, legislative, and executive-participated in dismantling the First Reconstruction. The resulting legal acceptance of harsh discrimination reinforced ongoing, widespread violence against Blacks and other minorities in the United States. ${ }^{41}$

Judicial retrenchment began almost immediately with the sharp narrowing of the privileges and immunities protections of the Fourteenth Amendment. Going well beyond the Constitution's text in The Slaughterhouse Cases, ${ }^{42}$ the Court first distinguished the rights of state citizenship from those of national citizenship. It then held that the Privileges and Immunities Clause protected only a limited range of "national rights" such as the right to travel, and otherwise left states free to discriminate. 43

The Court next invalidated the significant public accommodation provisions of the 1875 Civil Rights Act by narrowing the scope of civil rights law to exclude "social rights." 44 The majority in the Civil Rights Cases concluded that "[m]ere discriminations on account of race or color" in restaurants, hotels and theaters involve private social rights, not state action, and

color, regardless of any previous condition of servitude")).

40 BELL, supra note 26 , at 43-44 \& nn.13-16.

41 See, e.g. Harris, supra note 5, at 1968-69 (discussing the "quasi-legal" status of lynchings during the Jim Crow era) and at 1943-44 (discussing the Chinese Exclusion Act, ch. 60, 27 Stat. 25 (1892)).

4283 U.S. (16 Wall.) 36 (1872).

43 Id. at 77-78; see. also United States v. Cruikshank, 92 U.S. 542 (1875) (dismissing indictments in the 1873 Colfax massacre, in which several hundred armed Whites burned a courthouse and killed more than one hundred Black men holding a public assembly in a courthouse over a disputed gubernatorial election on the grounds that the rights violated were not those protected by the Constitution or any law of Congress); United States v. Reese, 92 U.S. 214 (1875) (invalidating provisions of the Enforcement Act of 1870 used to indict a Kentucky registrar who refused to count an African American's vote).

4 Civil Rights Cases, 109 U.S. 3, 25 (1883). 
therefore are not prohibited by the Fourteenth Amendment. ${ }^{45}$ The Court therefore declared the Civil Rights Act of 1875 unconstitutional. ${ }^{46}$ The law accepted "social" segregation, even in public accommodation. As a result, many states not only practiced discrimination, they enacted it into law. These laws coupled with the withdrawal of federal troops from the South as part of a compromise resolution of the contested 1876 presidential election devastated civil rights for African Americans.47 Federal criminal enforcement of civil rights, for instance, dramatically decreased from 1,304 prosecutions in 1873 to twentyfive in 1878.48

The infamous "separate but equal" doctrine followed. That doctrine undermined the equal protection rights of Blacks. In Plessy v. Ferguson ${ }^{49}$ the Court observed that the Fourteenth Amendment "could not have been intended to abolish distinctions based upon color, or to enforce social, as distinguished from political equality, or a commingling of the two races upon terms unsatisfactory to either." 50

White supremacy campaigns that began shortly after the civil war were fueled by an environment of suspicion and fear bred by this legally-sanctioned separation of races. ${ }^{51}$ Thousands of lynchings of African Americans took place, often under the watchful eye of government law officials. Indeed, one prosecutor dismissed the lynchings as "an expression of the

$45 \quad I d$. (also finding inapplicable the Thirteenth Amendment's ban on slavery).

46 Id.; see also United States v. Harris, 106 U.S. 629 (1882) (striking down the Ku Klux Klan Act of 1871 on the grounds that protection of individuals from private conspiracies is a state not a federal function).

4 BELL, supra note 26, at 51-53 (describing the Hayes-Tilden compromise).

48 Harry A. Blackmun, Section 1983 and Federal Protection of Individual Rights--Will the Statute Remain Alive or Fade Away, 60 N.Y.U. L. REV. 1, 11 (1985).

$49 \quad 163$ U.S. 537 (1896) (upholding state statute barring persons from occupying passenger train cars other than those to which their race had been assigned), rev'd, 347 U.S. 483 (1954); see also Cheryl I. Harris, Whiteness As Property, 106 Harv. L. Rev. 1709, $1745-1750$ (1993) (analyzing Plessy in terms of a property interest in Whiteness).

50 Plessy, 163 U.S. at 544; see also Cumming v. Richmond County Bd. of Educ., 175 U.S. 528 (1899) (refusing to reinstate injunction prohibiting state board from collecting school tax levies for the maintenance of a high school system that solely benefited Whites until equal facilities were provided for African American students); Berea Coll. v. Kentucky, 211 U.S. 45 (1908) (upholding statute subjecting a private college to a heavy fine for admitting both White and Black students). In a prescient dissent to Berea College, Justice Harlan observed that if a state could limit the association of White and Black persons in private schools, it could also bar minority religious and nationality groups not only from schools but from churches, the marketplace and other public places. Id. at 69 .

51 See United States v. Price, 383 U.S. 787, 804-05 (1966) (discussing the rise of White supremacy groups, such as the Klu Klux Klan). 
will of the people." 52 Parallel attacks on immigrants and other minorities also took place during this period. As the United States Commission on Civil Rights recognized, "Asian Americans share with American Blacks the distinction of having been the targets of widespread legal discrimination that hindered their ability to participate fully in the American dream." 53

Both Congress and state legislatures also played a significant part in dismantling the First Reconstruction. The period from 1890 to 1910 witnessed a steady rise of state Jim Crow statutes in both the North and South. ${ }^{54}$ Efforts to prevent social contact between the supposedly superior and inferior races applied to both public and private facilities. Discriminatory state laws called for segregation in virtually all aspects of society. ${ }^{55}$

In 1894, Congress repealed thirty-nine sections of the civil rights voting laws. ${ }^{56}$ Even where civil rights laws remained, and where states clearly violated those laws to prevent African Americans from voting, the Court refused to order injunctive relief on grounds of the political volatility of the issue. ${ }^{57}$

The executive branch joined the judicial and the legislative branches in effectively dismantling the First Reconstruction. The Department of Justice, for example, proudly asserted that it had adopted a policy of "strict self-limitation with regard to

52 BELL, supra note 26, at 461 n.1 (quoting M. BELKNAP, FEDERAL LAW AND SOUTHERN ORDER 8-9 (1987)); see also Harris, supra note 5, at 1966-69 (describing how the "blurriness" of the line between legal and social spheres after Plessy permitted government complicity in the face of horrific violence against African Americans, and suggesting that racial violence actually attained quasi-legal status through government acquiescence and inaction); Barbara Holden-Smith, Lynching, Federalism, and the Intersection of Race and Gender in the Progressive Era, 8 YALE J.L. \& FEMINISM 31 (1996); Harris, supra note 5, at 1966-69 (describing how "private" acts of terror against African Americans often had the force of law).

53 U.S. COMMISSION ON CIVIL RIGHTS, CIVIL RIGHTS ISSUES FACING ASIAN AMERICANS IN THE 1990S 6-7 (1992); see also Harris, supra note 5, at 1969 (proposing that racial violence against Chinese and other non-White Americans had the purpose or effect of expressing that the victims were not entitled to equal status in the social realm).

54 See generally C. Vann Woodward, The Strange Career of Jim Crow (3d ed. 1974).

55 John Hope Franklin, History of Racial Segregation in the United States, in ANNALS AM. ACAD. POL. \& SOC. SCI. 341 (Mar. 1956)

56 BLACKMUN, supra note 48 , at 11.

57 See Giles v. Harris, 189 U.S. 475 (1903) (denying request for injunctive relief against state constitutional provision); see also Giles v. Teasley, 193 U.S. 146 (1904); James v. Bowman, 190 U.S. 127 (1923) (denying federal authority to prosecute individual who prevented Kentucky Blacks from voting in a congressional election through an act of bribery); Guinn v. United States, 238 U.S. 347 (1915) ("grandfather clauses" do not violate constitutional rights); Breedlove v. Shuttles, 302 U.S. 277 (1937) (poll taxes do not violate constitutional rights). 
prosecutions under the civil rights acts."58 Furthermore, "[u]ntil 1949, [Federal Housing Administration] official policy was to refuse to insure any unsegregated housing. It was not until ... 1962 that the Agency required nondiscrimination pledges from loan applicants." 59

Although the Civil Rights Acts and constitutional amendments remained, their promise had been eviscerated by the "social rights" exclusion from antidiscrimination law and by ensuing states' Jim Crow laws covering voting, public accommodations, jobs, transportation, education, and housing. All three branches of government participated in the piece by piece dismantling of on-the-books civil rights protections for Blacks. The demise of the First Reconstruction paved the way for a fully segregated American society, one that was separate and starkly unequal-a society at profound dissonance with the nation's professed moral creed that "all are created equal."

\section{B. The Second (Contemporary) Reconstruction}

The Second Reconstruction offered a renewed commitment to civil rights for African Americans and other subordinated communities of color. Substantial African American contributions to the war effort, ${ }^{60}$ the massive social, legal, and political movement launched by antiracist activists, and the legal reforms of the 1950s and 1960s - highlighted by Brown v. Board of Education, 61 and culminating in the enactment of the Civil Rights Act of 1964 and Voting Rights Act of 1965-laid the foundation for the Second Reconstruction. ${ }^{62}$ Together with the

58 Screws v. United States, 325 U.S. 91, 159 (1945) (Roberts, J., dissenting).

59 Report of the National Advisory COMmission ON Civil Disorders 260 (1968).

60 See Harris, supra note 5 , at 1987-881

The end of the war sparked a new activism in groups considered nonwhite. Returning African American and Mexican American troops found Jim Crow impossible to stomach after having served their country with honor and distinction, and often after having been treated as equals by white Europeans. In the post-war period, anti-racist activists, working both through local, grass roots groups and national organizations like the League of United Latin American Citizens (LULAC) and the National Association for the Advancement of Colored People (NAACP) began to campaign vigorously to end American apartheid.

Id.

61347 U.S. 483 (1954); see also RICHARD KLUGER, SIMPLE JUSTICE: THE HISTORY OF BROWN V. BOARD OF EDUCATION AND BLACK AMERICA'S STRUGGLE FOR EQUALITY (1975).

62 Civil Rights Act of 1964,78 Stat. 241 (codified at 28 U.S.C. \$1447, 42 U.S.C. \$S 1971, 1975a-1975d, 2000a-2000h6 (1994)); Voting Rights Act of 1965, 79 Stat. 437 (codi- 
resurrection of the Civil Rights Act of $1870^{63}$ and the advent of affirmative action, these legal reforms collectively renewed the nation's commitment to civil rights and, even more important, to equality and justice. 64

Brown in 1954 breathed new life into the Equal Protection Clause in the face of pervasive segregation and continuing racial violence. ${ }^{65}$ In outlawing state-mandated segregation, Brown offered the promise of equal treatment for African Americans and compelled national acknowledgment of entrenched forms of racial discrimination. In the years following Brown, the Supreme Court nullified Jim Crow policies in streetcars, buses, cafeterias, golf courses, swimming pools, and courtrooms. ${ }^{66}$

In the decade that followed, with the support of progressive Whites and other communities of color, Blacks struggled to achieve equality despite massive resistance by Southern Whites. ${ }^{67}$ In response to post-Brown resistance, continuing dis-

fied at 42 U.S.C. $\$ 1973$ et seq. (1994)); see MANNING MARABLE, RACE, REFORM AND REBELLION: ThE SECOND RECONSTRUCTION IN AMERICA, 1945-1990 (1991) (“The Second Reconstruction was a series of massive confrontations concerning the status of African-American and other national minorities (e.g., Indians, Chicanos, Puerto Ricans, Asians) in the nation's economic, social and political institutions.").

${ }^{6} 3$ See Harris, supra note 5, at 1993-94 (discussing the Warren Court's "resuscitat[ion" of the First Reconstruction civil rights statutes, including 42 U.S.C. \$5 1981, 1982, 1983).

ot See generally id. at 1989-96. Harris aptly describes the range of social and political forces underlying the Second Reconstruction:

Between the late 1940s and the late 1960s, antiracist activists - most notably those in the African American civil rights and "Black Power" movements - successfully cultivated the seeds of antidiscrimination law found in cases like Carolene Products and even in Plessy itself. Their legal and political efforts, combined with a massive grass roots social movement of a scale and moral power not seen since abolitionism, and coupled with the new political and social vulnerability of racial segregation and discrimination, eventually forced the United States into a political crisis. The outcome of that crisis was the so-called Second Reconstruction: a movement within both Congress and the Supreme Court to uproot de jure racial segregation, to create new legal tools to fight discrimination, and to breathe new life into the long-forgotten remnants of the First Reconstruction.

Id. at 1989. Professor Harris posits that "the Second Reconstruction consisted of three elements: civil rights law from the First Reconstruction, new legislation from Congress, and a withdrawal from various doctrines of plenary power." Id.

65 BELL, supra note 26, at 170 . A year later, however, the Court issued a separate ruling in Brown II, 349 U.S. 294 (1955), directing the enforcement of Brown I's desegregation decree with "all deliberate speed," essentially permitting Southern Whites to resist the requirements of Brown I. Id. at 167-170.

66 Id. at 278; see also Harris, supra note 5, at 1991 (describing how the Court during this period also outlawed racially restrictive covenants, restricted the states' ability to persecute civil rights organizations and demonstrators, held unconstitutional anti-Asian land laws, and prohibited antimiscegenation statutes).

67 See generally BELL, supra note 26 , at $166-70$. 
crimination, and virulent White supremacy, the Civil Rights Movement pushed Congress to pass the Civil Rights Act of 1964, the Voting Rights Act of 1965, and the Fair Housing Act of 1968.68 Cumulatively, the 1964 Civil Rights Act expressly outlawed racial, national origin, religion, and gender discrimination in public facilities, employment, education, and other federally funded activities. ${ }^{69}$ The legislation-directed primarily at removing the barriers to equal opportunity for African Americans-solidified America's commitment to federal protection for these targets of discrimination. ${ }^{70}$ The legislation was not meant to be colorblind; it took express account of the social and political significance of race. ${ }^{71}$ In particular, Title VI of the Act, as construed in Guardians Association v. Civil Service Commissionn of New York City,72 authorized federal agencies to promulgate appropriate regulations to combat "disparate impact" discrimination - that is, discrimination against groups regardless of the "intent" of the discriminator. Title VI, section 602, now challenged in Sandoval, was an integral part of the civil rights laws comprising the Second Reconstruction.

Court rulings following the enactment of the Civil Rights Act of 1964 confirmed the validity of "disparate impact" challenges to discriminatory practices. In the landmark case of Griggs v. Duke Power Co., ${ }^{73}$ the United States Supreme Court

6 During this time period, Congress also passed the Immigration and Nationality Act of 1965, Pub. L. No. 89-236, 79 Stat. 911 (1965) (abolishing restrictions on immigration based on race, religion and nationality).

69 The separate Titles of the 1964 Civil Rights Act protect different groups. For instance, with respect to federally funded entities, Title VI proscribes discrimination based on race, color, and national origin, see 42 U.S.C. $\$ 2000 \mathrm{~d}$ et seq., and Title IX addresses gender discrimination, see 20 U.S.C. $\$ 1681$ et seq. With respect to employment, Title VII prohibits discrimination on the basis of race, color, religion, sex, and national origin. See 42 U.S.C. $\$ 2000 \mathrm{e}-2$.

oo As Professor Harris observes,

In addition to creating private rights of action to enforce the Act, Congress created a new federal agency, the Equal Employment Opportunity Commission (EEOC), and gave it the power to investigate complaints and issue regulations under the Act. Several years later the EEOC received the power to institute civil actions on its own.

Harris, supra note 5, at 1994.

$\pi$ In passing the Civil Rights Act of 1964, Congress expressly recognized that the "most glaring" discrimination against any minority group in America was against "Negroes," who, " 100 years after their formal emancipation," were "not accorded the rights, privileges, and opportunities which are considered to be, and must be the birthright of all citizens." H.R. REP. NO. 914, 88th Cong., (2d Sess. 1964), reprinted in 1964 U.S.C.C.A.N. 2393. Congress clearly intended the federal legislation to secure those rights, state and local progress having been deemed "too slow." Id.

72463 U.S. $582(1983)$.

73401 U.S. 424 (1971). 
first made clear that Title VII prohibits facially neutral employment practices in disparate impact cases if those practices operate to maintain the status quo of prior discrimination. Twelve years later in Guardians, the Court determined that the administrative regulations implementing Title VI of the Civil Rights Act were valid and, accordingly, Title VI reached unintentional, disparate-impact discrimination as well as deliberate racial discrimination. ${ }^{74}$

In addition, the Voting Rights Act of 1965 opened up the polls to all African Americans for the first time since the end of the First Reconstruction. ${ }^{75}$ Its elaborate measures created "an affirmative right to vote, instead of just a negative right to be free of discrimination in voting." 76 The enactment of the Civil Rights and Voting Rights Acts thus reinforced the guarantees of the Reconstruction amendments and signaled the fall of Jim Crow.

Initial reactive legal challenges to the Second Reconstruction failed. In a series of cases, the Supreme Court upheld the constitutionality of both the Civil Rights and Voting Rights Acts. In Heart of Atlanta Motel, Inc. v. United States, 77 the Supreme Court upheld the constitutionality of Title II (addressing public accommodations) as a proper exercise of Congress' authority under the Commerce Clause. In the same year, in Katzenbach $v$. McClung, ${ }^{78}$ the Court again confirmed the constitutional validity of Title II. In South Carolina v. Katzenbach, ${ }^{79}$ the Court soundly rejected a constitutional challenge to the Voting Rights Act and held that the Act "reflects Congress' firm intention to rid the country of racial discrimination in voting." Finally, in

74 Guardians, 463 U.S. at 589:93. At around the same period, Congress passed the Immigration and Nationality Act of 1965, Pub. L. No. 89-236, 79 Stat. 911 (1965), which abolished restrictions on immigration based on race, religion and nationality, and the Fair Housing Act of 1968 (prohibiting discrimination on grounds of race, color, religion or national origin in the sale or rental of housing).

75 See Harris, supra note 5, at 1994 (observing that the Act "had an immediate and dramatic effect on minority voting and political participation, bringing thousands of citizens into electoral politics for the first time.")

76 Alan Freeman, Antidiscrimination Law: The View from 1989, in THE PoLrrICS OF LAW 121, 130 (D. Kairys, ed. 1990); see also Drew S. Days, III \& Lani Guinier, Enforcement of Section 5 of the Voting Rights Act, in MINORITY VOTE DILUTION 167, 167-68 (Chandler Davidson ed., 1984) (observing that Section 5 of the Voting Rights Act of 1965 was particularly important because its goal was to "shift the advantage of time and inertia" from wrongdoers to the victims of discrimination); Harris, supra note 5, at 1994.

379 U.S. 241 (1964).

379 U.S. 294 (1964).

383 U.S. 301,315 (1966). 
Katzenbach v. Morgan, ${ }^{80}$ the Court upheld Section 4(e) of the Voting Rights Act as a valid exercise of Congress' powers under Section Five of the Fourteenth Amendment.

At the same time, the Court gave new life to First Reconstruction civil rights statutes. ${ }^{81}$ In Monroe $v$. Pape, ${ }^{82}$ the Court held that victims of police brutality could state a claim against police officers and city officials under 42 U.S.C. \& 1983 (an original First Reconstruction civil rights law) because such brutality was carried out "under color of" state law within the meaning of the statute. Then, in Jones v. Alfred H. Mayer Co., 83 the Court held that 42 U.S.C. $\$ 1982$ bars both private and public racial discrimination in the sale or rental of property and confirmed that the statute was a valid exercise of Congress' powers under the Thirteenth Amendment. ${ }^{84}$ Collectively, the Court's rulings during this period provided judicial legitimacy to congressional and executive actions protecting the civil rights of racial minorities and reinforced the legal foundation of the Second Reconstruction. ${ }^{85}$

Over time, the antidiscrimination laws, executive actions, and court decrees of the Second Reconstruction compelled governmental prohibition of racial discrimination, established affirmative action, and generated expanded opportunities and structural improvements for African Americans and other communities of color in America. ${ }^{86}$

\footnotetext{
Bo 384 U.S. 641 (1966).

81 Harris, supra note 5, at $1989-90$.

s2 365 U.S. 167 (1961), overruled by Monell v. Department of Soc. Servs., 436 U.S. $658(1978)$

$83 \quad 392$ U.S. 409 (1968).

B. The Supreme Court later extended $\S 1981$ protections to private contracts. See Harris, supra note 5, at 1992 (citing Runyon v. McCrary, 427 U.S. 160 (1976).

B5 The executive branch also recommitted itself to providing real equality and justice to African Americans and other subordinated Americans. In 1961, for example, President Kennedy signed Executive Order 10925, which compelled contractors with the federal government to do more than ensure "equal opportunity" - it required them "to take 'affirmative action' to ensure that discrimination did not occur." Harris, supra note 5, at 1995. Later, in 1968, the Office of Federal Contract Compliance enacted a new code requiring contractors and large subcontractors to develop "affirmative action plans." ld. As Professor Harris observes, "[ $\mathrm{t}]$ he creation and operation of affirmative action programs, both voluntary and mandatory, contributed to a surge of people of color into areas of employment and higher education from which they had previously been excluded." Id.

B6 See Harris, supra note 5, at 1989-96.
} 


\section{Dismantling the Second Reconstruction: The Re-Legalization of Discrimination}

The legal reforms and social movements that comprised the Second Reconstruction resulted in significant changes for African Americans, Latinos, Asian Americans, women, and immigrants. These changes included expanded job opportunities, increased access to education, a decrease in state sponsored racial violence, immigration reform that offered citizenship to many non-Whites, and a moratorium on the application of the death penalty. ${ }^{87}$

But the victories were short lived. African Americans and the country never realized the full promise of these reforms. As with the First Reconstruction, since the mid-1970s, conservative groups have successfully waged systematic legal attacks in the courts and legislatures, along with a cultural and political crusade through ballot initiatives and the mainstream media. 88

These attacks, both direct and indirect, have had real consequences. For example, the incarceration rate for African American males is over four times higher than that of Whites. ${ }^{89}$ Racial

87 See, e.g., Luke Charles Harris \& Uma Narayan, Affirmative Action as Equalizing Opportunity: Challenging the Myth of "Preferential Treatment," 16 NAT'L BLACK L.J. 127, 131-32 (1999-2000) (reporting that "the proportion of employed Blacks who hold middle class jobs rose from 13.4 percent in 1960 to 37.8 percent in 1981 ... [and that] [ $t$ ]he number of Black college students rose from 340,000 in 1966 to more than one million in 1982") (citing ROBERT BLAUNER, BLACK Lives, WHITE LIVES: THREE DECADES OF RACE RELATIONS IN AMERICA (1989); Harris, supra note 5, at 1991-92 (observing that "[t]he fall of Jim Crow was accompanied by new constitutional restrictions on the power of the police to maintain racial order .... These restrictions on police discretion made it increasingly difficult for the police to act as the enforcement arm of white supremacy"); Kevin R. Johnson, Civil Rights and Immigration: Challenges for the Latino Community in the Twenty-First Century, 8 LA RAZA L.J. 42, 80-81 (1995) (discussing the impact of the 1965 repeal of national origin quotas in U.S. immigration law on the racial and ethnic communities of the U.S.) (citing inter alia, U.S. Dep't of Justice, 1992 Statistical Yearbook of the Immigration and Naturalization Service 27-28 (1993)); U.S. Dep't of Justice, Introduction, The Federal Death Penalty System: A Statistical Survey (1988-2000) (stating that "[ $t]$ he Supreme Court issued a ruling in 1972 that had the effect of invalidating capital punishment throughout the United States-both in the federal criminal justice system and in all the states that then provided for the death penalty") (referring to Furman v. Georgia, 408 U.S. 238 (1972)); Harris, supra note 5, at 1991-92 ("The fall of Jim Crow was accompanied by new constitutional restrictions on the power of the police to maintain racial order . ... These restrictions on police discretion made it increasingly difficult for the police to act as the enforcement arm of white supremacy.").

88 See Jean STEFancic \& Richard Delgado, No Mercy: How Conservative THINK TANKS AND FOUNDATIONS CHANGED AMERICA's SOCIAL AGENDA 139-154 (1996).

89 United States Department of Justice, Bureau of Justice Statistics, 1997 Study, available at http://www.ojp.usdoj.gov/bjs/gcorpop.htm\#CorrPopRace. 
minorities continue to face discrimination in employment, 90 housing, ${ }^{91}$ and access to health care. 92 White supremacist groups and anti-immigrant sentiment ${ }^{93}$ have grown. Statesponsored English-only laws, bans on bilingual education, antiimmigrant initiatives, and repeals of affirmative action programs impede racial minorities' full participation in American society. ${ }^{94}$ Many city public schools are segregated along racial

90 "Despite many federal efforts to provide equal employment opportunities regardless of race, such as Civil Rights Act of 1991, economic outcomes for African Americans persistently lag behind those of whites in the United States." General Accounting Office, Equal Employment Opportunity: Displacement Rates, Unemployment Spells, and Reemployment Wages by Race, Fact Sheet, 9/16/94, GAO/HEHS-94-229FS. Average African American wage rates and unemployment rates are consistently below those of Whites. Id. Even in times of economic growth, African Americans experienced the worst labor market outcomes regardless of the state of the economy. Minorities also suffer higher displacement rates when cutbacks are implemented. Id.; see also Linda Hamilton Krieger, The Content of Our Categories: A Cognitive Bias Approach to Discrimination and Equal Employment Opportunity, 47 STAN. L. REV, 1161 (1995) (discussing the failure of current employment discrimination law to address contemporary forms of discrimination).

91 For example, researchers in Boston found that Black and Hispanic applicants were over fifty percent more likely to be denied a mortgage loan than Whites, even after taking into account many factors relevant to the credit-granting decision. Anthony D. Taibi, Banking, Finance, and Community Economic Empowerment: Structural Economic theory, Procedural Civil Rights, and Substantive Racial justice, 107 HARV. L. REV. 1463, 1474-76) (1994). A report "by the Federal Reserve Board in 1991 revealed a wide gap between the mortgage denial rates for whites and those for other minorities." See BELL, supra note 26, at 315. "Among the highest income applicant group, the denial rate nationally for blacks was $21.4 \%$; for whites $8.5 \%$; for Asians $11.2 \%$." Id. at n.7; see also John O. Calmore, Racialized Space and the Culture of Segregation: "Hewing a Stone of Hope from a Mountain of Despair," 143 U. PA. L. REV. 1233 (1995) (identifyirg the relationship between residential segregation and formation of racial identity).

92 While the disparity in access between Whites and non-Whites can be partially explained in economic terms, racism is an independent factor resulting in disproportionate obstacles for people of color. This is illustrated by the fact that minorities whose source of payment is the same as that of Whites still receive less care. For instance, on a national level, African Americans receive one-half (in Southern states, one-third) as mariy coronary artery bypass operations as White patients with similar symptoms and source of payment. See RAND E. ROSENBLATT ET. AL., LAW AND THE AMERICAN HEALTH CARE SYSTEM 108-109 (1997) (quoted in Larry J. Pittman, Physician Assisted Suicide in the Dark Ward: The Intersection of the Thirteenth Amendment and Health Care Treatments Having Disproportionate lmpacts, 28 SETON HALL L. REV. 774, 820 n.195 (1998)). See generally Sylvia A. Law, A Right To Health Care That Cannot Be Taken Away: The Lessons Of Twenty-Five Years Of Health Care Advocacy, 61 TENN. L. Rev. 771, 789-92 (1994).

${ }_{93}$ See Nancy Cervantes, Sasha Khokha \& Bobbie Murray. Hate Unleashed: Los Angeles In The Aftermath of Proposition 187, 17 CHICANO-LATINO L. REv. 1 (1995); see also IMMIGRANTS OUT! THE NEW NATIVISM AND THE ANTI-IMMIGRANT IMPULSE IN THE UNITED STATES (Juan F. Perea ed., 1997); Kevin R. Johnson, Race, the Immigration Laww, and Domestic Race Relations: A "Magic Mirror" Into the Heart of Darkness, 73 IND. L.J. 1111 (1998); BILl ONG HING, MAKING AND REMAKING ASIAN AMERICA THROUGH IMMIGRATION POLICY 1850-1990 (1993).

7 Twenty-six states have enacted English-only laws. See Christian A. Garza, Measuring Language Rights along a Spectrum, 110 YALE L.J. 379, 386 n.2 (2000); Carey 
and ethnic lines, with marked differences in the quality of education. ${ }^{95}$

The direct attacks have been aimed at the specifics of civil rights legislation and anti-discrimination law doctrine. ${ }^{96}$ The indirect challenges have attempted to drastically restrict the federal government's role in enforcing civil rights. Ironically, the renewed call for "states' rights" and the refrains of "reverse discrimination," "racial preferences," and "colorblindness" have partly refocused civil rights on protecting the interests of White Americans. ${ }^{97}$ Politically, the success of these legal challenges and the pervasiveness of this popular rhetoric reveal an America close to again revoking its commitment to civil rights for African Americans and other racial minorities.

\section{Direct Challenges to Civil Rights}

The Civil Rights Act of 1964, the Voting Rights Act of 1965 and the landmark decisions that challenged over a century of invidious discrimination against minorities are now subject to direct challenge.

\section{a. The Fourteenth and Fifteenth Amendments}

Grounded in the Fourteenth and Fifteenth Amendments, the Second Reconstruction firmly established the federal government's role in protecting civil rights for African Americans and other minorities. ${ }^{98}$ Since the mid-1970s, however, the Supreme

Goldberg, The 2000 Elections: Ballot Initiatives, N.Y. TiMES, Nov. 8, 2000; see also Susan Kiyomi Serrano, Rethinking Race for Strict Scrutiny Purposes: Yniguez and the Racialization of English Only, 19 U. HAW. L. REV. 221 (1997); Juan F. Perea, Demography and Distrust: An Essay on American Languages, Cultural Pluralism, and Official English, 77 MINN. L. REV. 269 (1992); CALIFORNIA PROPOSITION 187 (restricting rights of immigrants) and CALIFORNIA PROPOSITION 209 (banning affirmative action programs).

93 BELL, supra note 26, at 214-15.

96 See Crenshaw, supra note 34; see also Yamamoto, infra note 109, at 850.

97 For example, California's Proposition 209, the anti-affirmative action initiative which was fueled by claims of "reverse discrimination" against innocent Whites, was called the "California Civil Rights Initiative." See Pete Wilson, Ward Connerly, Pamela A. Lewis, Argument in Favor or Proposition 209. CALIFORNIA BALLOT PAMPHLET: GENERAL ELECTION (1996) (arguing that affirmative action results in reverse discrimination).

93 See Mitchum v. Foster, 407 U.S. 238-39 (1972) ("As a result of the new structure of law that emerged in the post-Civil War era-and especially of the Fourteenth Amendment, which was its centerpiece - the role of the Federal Government as a guarantor of basic federal rights against state power was clearly established.") (citing Monroe v. Pape, 365 U.S. 167 (1961); McNeese v. Bd. of Educ., 373 U.S. 668 (1963); Shelley v. Kraemer, 334 U.S. 1 (1948); Zwickler v. Koota, 389 U.S. 241, 245-249 (1967)); 
Court's equal protection jurisprudence has reflected an increasing unwillingness to allow the government to carry out that role. In particular, the Court has adopted a restrictive view of discrimination that ignores many realities of contemporary racism. ${ }^{99}$ In Washington $v$. Davis, ${ }^{100}$ the Court significantly restricted the scope of unconstitutional discrimination by imposing a new "intent" requirement on plaintiffs alleging violations of the Equal Protection Clause. Statutes or policies that are facially neutral can now be challenged only with proof of the actual discriminatory intent of the individual or institutional actors-proof which is difficult to muster since a person's intent is often easily disguised. ${ }^{101}$ The standard adopted in Washington markedly limited the reach of the Equal Protection Clause by legally countenancing institutional and unconscious discriminatory practices. ${ }^{102}$

In McCleskey v. Kemp, ${ }^{103}$ for example, the Court denied a defendant's equal protection claim despite overwhelming evidence of racially discriminatory treatment of criminal defendants subject to the death penalty in Georgia. ${ }^{104}$ The Court placed a virtually impossible burden on the defendant by requiring proof that the death penalty statute was enacted inten-

H. FLACK, THE AdOPTION OF THE FOURTEENTH AMENDMENT (1908); J. TENBROEK, THE ANTI-SLAVERY ORIGINS OF THE FOURTEENTH AMENDMENT (1951); see also Saenz v. Roe, 526 U.S. 489 (1999) (citing J. TENBROEK, EQUAL UNDER LAW 201 (rev. ed. 1965).

99 See infra Section II.B.2 (discussing subconscious forms of discrimination).

100426 U.S. 229 (1976).

107 See Adarand Constructors, Inc. v. Pena, 515 U.S. 200, 246 (1995) ("A state actor inclined to subvert the Constitution might easily hide bad intentions in the guise of unintended 'effects' ...") (Stevens, J., dissenting); see also Charles R. Lawrence, III., The Id, the Ego and Equal Protection: Reckoning with Unconscious Racism, 39 STAN. L. REV. 317,319 (1987) (discussing the failure of the intent doctrine to acknowledge unconscious forms of discrimination); see infra Section II.B.

102 See infra Section II.B.2. In recent years, the Court has affirmed civil rights in a limited number of cases. See, e.g., Batson v. Kentucky, 476 U.S. 79, 89 (1986) (holding that the Equal Protection Clause forbids the prosecutor to challenge potential jurors solely on account of their race); Romer v. Evans, 517 U.S. 620, 623 (1996) (invalidating a Colorodo constitutional amendment prohibiting governmental efforts to protect homosexuals from discrimination); Lopez v. Monterey County, 525 U.S. 266, 269 (1999) (upholding challenge to county-wide election scheme based on alleged vote dilution under Voting Rights Act of 1965); Legal Services Corp. v. Velazquez, $121 \mathrm{~S}$. Ct. 1043, 1046 (2001) (invalidating restriction on Legal Services Corporation that would prevent grant recipients representing indigent clients from arguing that a state statute violates federal law).

103481 U.S. 279 (1987).

10t Id. at 286-291 (citing evidence from Baldus, Pulaski \& Woodsworth, Comparative Review of Death Sentences: An Empirical Study of the Georgia Experience, 74 J. CRIM. L. \& CRIMINOLOGY 661 (1983)). See generally Anthony V. Alfieri, Mitigation, Mercy, and Delay: The Moral Politics of Death Penalty Abolitionists, 31 HARv. C.R.-C.L. L. REv. 325 (1996) (discussing contemporary attempts at death penalty reforms and abolition). 
tionally to discriminate against African Americans. ${ }^{105}$ Racial disparities in the application of the death penalty continue to exist. 106 Under the Court's intent standard, however, many non-Whites on death row with plausible claims of racial discrimination in sentencing are left without redress. ${ }^{107}$ The Supreme Court's restrictive intent standard also has been employed to limit minority protections against discrimination in other areas of the law. 108

Yet, with unacknowledged irony, the Court has invoked the Fourteenth Amendment and the idea of "colorblindness" in favor of Whites to overturn governmental efforts to remedy the effects of long-standing discrimination against non-Whites. In Adarand Constructors, Inc. v. Peña, ${ }^{109}$ a reverse discrimination case brought by. White contractors, the Court held that all racial classifications-including affirmative action programs designed to remedy past discrimination-are subject to strict

105 The Court reasoned that, "[t]here was no evidence then, and there is none now, that the Georgia Legislature enacted the capital punishment statute to further a racially discriminatory purpose." McCleskey, 481 U.S. at 298.

106 For example, from 1988-1994, of the 52 defendants submitted by the US Attorneys' Office for the death penalty, $75 \%$ were Black, $10 \%$ Hispanic, and $13 \%$ White. From 1995 to 2000 , of the 682 submitted under current procedures, $48 \%$ Black, $29 \%$ Hispanic, 20\% White. U.S. Department of Justice, The Federal Death Penalty System: A Statistical Survey (1988-2000). In addition, a 1998 study in Philadelphia revealed that the odds of receiving the death penalty are four times greater for a Black defendant than a White one. David C. Baldus, et al., Racial Discrimination and the Death Penalty in the Post-Furman Era: An Empirical and Legal Overview, With Recent Findings From_Philadelphia, 83 CORNELL L. REV. 1638 (1998).

107 See generally Baldus, supra note 106. New legislation has also imposed stringent limitations of federal habeas petitions in capital cases. See Special Habeus Corpus Proceedings in Death Penalty Cases, Pub. L. No. 104-132, \$ 107(a), 110 Stat. 1214, 1221 (1996) (codified as amended at 28 U.S.C. $\$ 2261(2000)$ ). Despite the limited redress available in federal courts, the application of the death penalty is coming under increasing attack. For example, due to the striking number of "erroneous" death penalty convictions (more post-appeal determination of innocence than executions), Illinois" Republican governor halted all executions. See William Claiborne, Illinois Order on Executions Lauded; Governor Backs Moratorium After 13 Death Row Inmates Are Exonerated, WASH. POST, Feb. 1, 2000, at A2.

108 See, e.g., INS v. Elias-Zacarias, 502 U.S. 478 (1992) (rejecting asylum claim where applicant offered evidence that guerillas threatened retaliation if he refused to fight with them against the government, stating that evidence that persecutors were politically motivated was insufficient evidence that the applicant feared persecution "on account of" his political opinion); see also Krieger, supra note 90 (critiquing the requirement in Title VII disparate treatment cases that plaintiffs show discriminatory motive or intent).

109515 U.S. 200 (1995); see also Eric K. Yamamoto, Critical Race Praxis: Race Theory and Political Lawyering Practice in Post-Civil Rights America, 95 MiCH. L. REV. 821 (1997) (describing how the Court in Adarand used "colorblindness" ideologically to obscure the difference between race-conscious programs that support systemic subordinating and those endeavoring to dismantle it). 
scrutiny under the Equal Protection Clause and are, therefore, presumptively invalid. In City of Richmond $v$. Croson, 110 the Court determined that the City's detailed findings of its own past discrimination and the nation's widespread discrimination in the contracting industry were insufficient to justify local government race-based affirmative action.

In an apparent abandonment of its earlier support for remedial voting rights legislation, the Court also recently overturned several state redistricting plans designed to remedy unequal voting representation ${ }^{111}$-- a key component of the Second Reconstruction. ${ }^{112}$ Finally, federal courts appear poised to give up on school desegregation. The Supreme Court has struck down a number of school desegregation plans aimed at achieving equality in educational opportunity. ${ }^{113}$ In a new era

110488 U.S. 469 (1989); see also Thomas Ross, The Richmond Narratives, 68 TEX. L. REV. 381 (1989) (analyzing the narrative threads in Croson). Adarand and Croson have been used to invalidate affirmative action programs in higher education. See, e.g., Hopwood v. Texas, 78 F.3d 932, 940-41 (5th Cir. 1996), cert. denied, 518 U.S. 1033 (1996) (holding that the affirmative action admissions program of the university violated the constitutional rights of White applicants); Gruetter v. Bollinger, No. 97-CV-75928, 2001 WL 293196, at 23-29 (E.D. Mich. March 27, 2001) (invalidating Michigan law school's affirmative action policy and concluding that racial diversity is not a compelling state interest). But see Smith v. Univ. of Wash. Law School, 233 F.3d 1188, 1201 (concluding that the "Fourteen Amendment permits University amdissions programs which consider race for other than remedial purposes, and educational diversity is a compelling governmental interest that meets the demands of strict scrutiny of raceconscious measures.").

111 See e.g., Shaw v. Reno, 509 U.S. 630 (1993); Miller v. Johnson, 515 U.S. 900 (1995); Bush v. Vera, 517 U.S. 952 (1996); Shaw v. Hunt, 517 U.S. 899, 924 (1996) (discussing the Court's "unarticulated recognition of a new substantive due process right to 'color-blind' districting itself") (Stevens, J. dissenting). Effective enforcement of the Voting Rights Act will become especially crucial during the upcoming redistricting battles based on the 2000 census. See also BELL, supra note 26, at 628-26 (discussing, inter alia, the Voting Rights Act of 1965); Harris, supra note 5, at 1994 (describing the dramatic effect on minority voting participation after the enactment of the Voting Rights Act).

112 Indeed, the Voting Rights Act of the Second Reconstruction was necessitated by harsh state efforts through law and intimidation to deny African Americans their right to vote. See generally BELL, supra note 26, at 580-85 (discussing the use of poll taxes, literacy tests and racial gerrymandering to dilute Black votes). See also Bush $v$. Gore, 121 S. Ct. 525 (2000). The NAACP and other civil rights groups have recently filed a voting rights lawsuit on behalf of African American voters in Florida following the 2000 election. NAACP and National Civil Rights Groups File Florida Voting Rights Lawsuit to Eliminate Unfair Voting Practices, Jan. 10, 2001, available at < http://www.naa cp.org/communications/press_releases/florida/01102001.asp.>>

113 See, e.g., Missouri v. Jenkins, 515 U.S. 70 (1995); Pasadena City Bd. of Educ. v. Spangler, 427 U.S. 424 (1976); Milliken v. Bradley, 418 U.S. 717 (1974); see also Ho v. San Francisco Unified Sch. Dist., 965 F. Supp. 1316 (N.D. Cal. 1997) (holding that a desegregation order designed to dismantle a historically segregated school system now discriminates against Chinese Americans); Yamamoto, supra note 109, at 821-86 (analyzing Ho case). 
of de facto school segregation based on race, national origin, and class, these cases reflect an accelerating retreat from the Second Reconstruction's call to eliminate racial discrimination "root and branch."114

Most disturbing, the equal protection and voting rights cases discussed above mark the resurrection of the century-old distortion-of-reality approach for denying minority civil rights reflected in the Civil Rights Cases. ${ }^{115}$ In 1883, the Court struck down the first set of federal civil rights laws enacted to protect African Americans from segregation in public facilities. ${ }^{116} \mathrm{De}-$ spite stark discrimination, the Court concluded that federal civil rights laws could not trump the social rights of Whites and that, in any event, civil rights preferences for African Americans were no longer necessary and unfairly discriminated against Whites. ${ }^{117}$ Then, as now, the Court's civil rights jurisprudence denied the realities of ongoing discrimination against minorities.

114 Green v. County Sch. Bd. of New Kent County, Va., 391 U.S. 430, 438 (1968). In Green, the Supreme Court recognized that,

school boards . . . were . . . clearly charged with the affirmative duty to take whatever steps might be necessary to convert to a unitary system in which racial discrimination would be eliminated root and branch. The constitutional rights of Negro school children articulated in Brown I permit no less than this; and it was to this end that Brown II commanded school boards to bend their efforts.

Id. (citations omitted); see also Freeman v. Pitts, 503 U.S. 467, 490 (1992) ("[I]t must be acknowledged that the potential for discrimination and racial hostility is still present in our country, and its manifestations may emerge in new and subtle forms after the effects of de jure segregation have been eliminated."); Rose v. Mitchell, 443 U.S. 545, 558-59 (1979) ("[W]e also cannot deny that, 114 years after the close of the War Between the States ... racial and other forms of discrimination still remain a fact of life, in the administration of justice as in our society as a whole. Perhaps today that discrimination takes a form more subtle than before. But it is not less real or pernicious.").

115109 U.S. 3 (1883).

116 See id. at 26.

117 See id. at 25.

When a man has emerged from slavery, and by the aid of beneficent legislation has shaken off the inseparable concomitants of that state, there must be some stage in the progress of his elevation when he takes the rank of a mere citizen, and ceases to be the special favorite of the laws, and when his rights as a citizen, or a man, are to be protected in the ordinary modes by which other men's rights are protected.

Id.; see also United States v. Morrison, 529 U.S. 598, 602, 620-27 (2000) (relying on Civil Rights Cases as support for invalidating civil remedy provision of the Violence Against Women Act). 


\section{b. Title VII}

Title VII is a key provision of the Civil Rights Act of 1964 and the most important federal legislation outlawing employment discrimination. As with the current challenge to section 602 of Title VI in Sandoval, a plaintiff's ability to successfully challenge employment discrimination under Title VII is also under attack. In its recent rulings, the Court has narrowed the reach of Title VII.

Specifically, in the 1990s, the Court abandoned two decades of precedent and significantly increased the plaintiff's burden of proof in disparate treatment cases under Title VII. In St. Mary's Honor Center $v$. Hicks, ${ }^{118}$ the Supreme Court rejected the plaintiff's claim of racial discrimination even though he established a prima facie case and demonstrated that the defendant's proffered reasons for the discrimination were false. According to the Court, if the defendant produces some reason for the discriminatory action, it is not enough that the plaintiff show that reason to be false or illegitimate; the plaintiff must prove racial motivation. ${ }^{119}$ This holding fails to recognize that contemporary racism, both intentional and subconscious, is often disguised. ${ }^{120}$

The import of the landmark disparate impact case, Griggs $v$. Duke Power Co., ${ }^{121}$ which recognized that even ostensibly neutral practices could be violative of Title VII if they discriminate in effect, has also has been seriously undermined. In Wards Cove Packing Co., Inc. $v$. Antonio, ${ }^{122}$ the Court imposed a new burden on plaintiffs by requiring that they identify "a specific or particular employment practice that has created the disparate impact under attack." 123 The Court's stated concern was that employers may be held "liable for 'the myriad of innocent causes that may lead to statistical imbalances in the composi-

118509 U.S. 502 (1993).

119 Id. at 508 . This Court confirmed the reasoning of the district court that, "'although [respondent] has proven the existence of a crusade to terminate him, he has not proven that the crusade was racially rather than personally motivated." $1 d$. at 508 (citation omitted).

120) See infra Section II.B.2 (discussing how discrimination actually occurs).

121401 U.S. 424 (1971).

122490 U.S. 642 (1989). In Wards Cove, the Court rejected the disparate impact claim by primarily Filipino and Alaskan native cannery workers that they were overrepresented in lower paid cannery jobs. Id. at 647-61.

123 Id. at 657; see Ian F. Haney Lopez, Institutional Racism: Judicial Conduct and a New Theory of Racial Discrimination, 109 YALE L.J. 1717, 1884 n.445 (2000) (discussing impact of Wards Cove). 
tion of their work forces." 124 This reference to "innocent causes" effectively imports into Title VII disparate impact doctrine an intent requirement and suggests that racially disproportionate results do not indicate racial discrimination. ${ }^{125}$

\section{c. Title VI}

Court rulings interpreting Title VI further reveal the hastening erosion of America's commitment to civil rights enforcement. In Regents of the University of California $v$. Bakke, ${ }^{126}$ the Court determined that Section 601 of Title VI proscribes only those racial classifications that violate the Equal Protection Clause-that is, only those that satisfy the intent-todiscriminate requirement. ${ }^{127}$ As discussed later, amici supporting the State of Alabama in Sandoval now argue that under Washington $v$. Davis, the Court should recognize a Title VI, Section 602 violation only if the plaintiffs prove actual intent to discriminate. ${ }^{128}$

2. Indirect Challenges to Federal Authority Over the States With Far-Reaching Consequences for Civil Rights Enforcement

Present-day civil rights retrenchment has accelerated with the expansion of states' sovereign immunity under the Eleventh Amendment and the bolstering of "states' rights" through restrictions on Congress' Commerce Clause power-the Supreme Court's "new federalism." 129 This sharp restriction on

124 Wards Cove, 401 U.S. at 657. (citation omitted).

125 See Haney Lopez, supra note 123. Attacks have also been launched against court-ordered measures providing remedies for proven discrimination under Title VII. Oftentimes, challenges have been driven by claims that such measures adversely impact "innocent whites." See generally Martin v. Wilks, 490 U.S. 755 (1989) (holding that White firefighters who had failed to intervene in earlier employment discrimination proceedings could collaterally challenge employment decisions taken pursuant to consent decrees).

126438 U.S. 265 (1978).

127438 U.S. at 287; see also United States v. Fordice, 505 U.S. 717, 732 (1992) (restating that the reach of Section 601 of Title VI extends only as far as the Fourteenth Amendment). In Guardians Ass' $n$ v. Civil Serv. Comm' $n$, Justice White, along with four other Justices recognized that in Bakke, "Title VI on its own bottom reaches no further than the Constitution." 463 U.S. 582, 589-90.

128 See Brief Amicus Curiae of Pacific Legal Foundation and Center for Equal Opportunity in support of Petitioner, Nov. 13, 2000, at 5-11, Alexander v. Sandoval (No. 99-1908).

129 See, e.g., Printz v. United States, 521 U.S. 898 (1997) (holding that federal government cannot commandeer state officials to enforce federal laws); City of Boerne v. 
federal power has eroded the ability of individuals to hold accountable states that openly or covertly discriminate. ${ }^{130}$

In recent cases, the Court has eviscerated congressional authority to abrogate states' sovereign immunity. It has solidified its new federalism by narrowly construing Congress' Commerce Clause authority and Congress' enforcement powers under the Fourteenth Amendment to prevent Congress from waiving states' sovereign immunity from private suits in both federal and state courts. ${ }^{131}$ As a consequence, a private citizen's monetary remedy for state-sponsored discrimination that violates federal civil rights legislation is sharply limited. The remedy is available only if the discriminating state has consented to suit and the federal legislation survives judicial scrutiny under section five of the Fourteenth Amendment. ${ }^{132}$ These two

Flores, 521 U.S. 507, 536 (1997) (determining that federal government may not exercise its power to criminalize conduct in a manner that "contradicts vital principles necessary to maintain separation of powers and the federal balance"); United States $v$. Lopez, 514 U.S. 549, 567-68 (1995) (invoking distinction between "what is truly national and what is truly local" to hold that Congress' Commerce Clause authority does not include a general police power akin to that retained by the states); Brecht $v$. Abrahamson, 507 U.S. 619, 635 (1993) (declaring that the sovereignty retained by the states in the Tenth Amendment includes the "primary authority for defining and enforcing the criminal law") (citation omitted); New York v. United States, 505 U.S. 144, 155-159 (1992) (reifying principles of structural federalism). See generally Jenna Bednar \& William N. Eskridge, Jr., Steadying the Court's "Unsteady Path": A Theory of Judicial Enforcement of Federalism, 68 S. CAL. L. REV. 1447 (1995); Stephen Gardbaum, Rethinking Constitutional Federalism, 74 TEX. L. REV. 795 (1996); Richard E. Levy, New York v. United States: An Essay on the Uses and Misuses of Precedent, History, and Policy in Determining the Scope of Federal Power, 41 U. KAN. L. REV. 493 (1993); Laurence H. Tribe, Unraveling National League of Cities: The New Federalisin and Affirmative Rights to Essential Governmental Services, 90 HARV. L. REV. 1065 (1977). But see Bush v. Gore, 121 S. Ct. 525 (2000) (holding that state supreme court's interpretation of state election law presented a federal constitutional question).

130 See Mitchell F. Crusto, The Supreme Court's "New" Federalism: An Anti-Rights Agenda?, 16 GA. ST. U. L. REV. 517 (2000) (arguing that the Court's new federalism encroaches upon constitutionally-protected civil rights); Richard E. Levy, Federalisin: The Next Generation, 33 LOY. L.A. L. REV. 1629 (2000) (analyzing the impact of the Court's new federalism on the Reconstruction Amendments and the spending power).

131 See Kimel v. Florida Bd. of Regents, 528 U.S. 62 (2000) (clear statement abrogating states' sovereign immunity unconstitutional exercise both of Congress' Commerce Clause authority and, under the Fourteenth Amendment, of its section 5 power to enforce equal protection clause); Alden v. Maine, 527 U.S. 706 (1999) (Congress lacks authority under the Commerce Clause to subject non-consenting states to suit in state courts); Florida Prepaid Postsecondary Educ. Expense Bd. v. College Sav. Bank, 527 U.S. 627 (1999) (abrogation of state sovereign immunity in Patent Remedy Act invalid exercise of Section 5 authority to enforce Due Process Clause); Seminole Tribe of Florida v. Florida, 517 U.S. 44 (1996) (Congress lacks authority under the Indian Commerce Clause to subject non-consenting states to suit in federal courts).

132 See, e.g., Kimel, 528 U.S. at 81 ("' $[t]$ here must be a congruence and proportionality between the injury to be prevented or remedied and the means adopted to that end," quoting City of Boerne v. Flores, 521 U.S. 507, 520 (1997)). Thus, to survive 
preconditions will rarely, if ever, be simultaneously met. ${ }^{133}$ For example, in its most recent pronouncement, Board of Trustees of the University of Alabama $v$. Garrett, ${ }^{134}$ the Court held that because Title I of the Americans with Disabilities Act was not "appropriate legislation" to enforce the Equal Protection Clause, state sovereign immunity barred disabled Americans from recovering money damages under the Act for state sponsored discrimination. ${ }^{135}$ Moreover, even where congressional authority exists, the Court's "new federalism" eviscerates civil rights protections because a state that harbors no qualms about discriminating in the first instance will not likely consent to suit against it for its acts of discrimination.

The practical effect of the recent resurgence of states' immunity from suit is that the Commerce Clause and Fourteenth Amendment are rapidly withering as the constitutional sources authorizing the enactment and enforcement of federal civil rights laws against the states. ${ }^{136}$ This modern judicial preclusion of private redress for violations of federal civil rights law.s harkens back to-and, indeed, expressly relies upon-cases crucial to the demise of the First Reconstruction. For example, in United States $v$. Morrison, ${ }^{137}$ the Court recently struck down the civil remedy provision of the Violence Against Women Act that provided a federal claim for gender-motivated acts of violence. As authority for its holding, the Court cited two cases crucial to the demise of the First Reconstruction, Harris and the Civil Rights Cases, for the broad proposition that the Fourteenth

judicial scrutiny under section five of the Fourteenth Amendment, civil rights legislation must redress a "widespread pattern of ... discrimination in this country" against whatever group the legislation seeks to protect and must not be "so out of proportion to a supposed remedial or preventive object that it cannot be understood as responsive to, or designed to prevent, unconstitutional behavior." Id. at 82 (quoting Flores, 521 U.S. at 531-32); see also Bd. of Trs. of the Univ. of Ala. v. Garrett, 121 S. Ct. 955 (2001) (holding that Title $\mathrm{I}$ of the Americans with Disabilities Act not "appropriate legislation" under section 5 of the Fourteenth Amendment and that remedies authorized under ADA are neither congruent nor proportional to the purported constitutional violation); College Sav. Bank, 527 U.S. at 675-87 (determining that state's activities in interstate commerce did not amount to consent to suit nor waiver of sovereign immunity); Lèvy, supra note 133.

133 See, e.g., Garrett, 121 S. Ct. 955 (Title I of Americans with Disabilities Act invalid exercise of section 5 authority to enforce equal protection clause); Kimel, 528 U.S. 62 (abrogation of state sovereign immunity in Age Discrimination in Employment Act invalid exercise of section 5 authority to enforce equal protection clause); College Sav. Bank, 527 U.S. 666.

$134121 \mathrm{~S}$. Ct. 955 (2001).

135 Id. at 968 .

136 See Crusto, supra note 130; Levy, supra note 130.

137121 S. Ct. 1740 (2000). 
Amendment does not reach private interactions, even though those "interactions" have significant nationwide impact. ${ }^{138}$ Invoking those clearly anti-civil rights cases as precedent highlights the Court's contemporary retreat from federal civil rights enforcement and signals its willingness to accept an expanding array of discriminatory acts. ${ }^{139}$

Also contributing to the civil rights retrenchment are recent Commerce Clause cases redefining the meaning of "interstate commerce." In United States v. Lopez, ${ }^{140}$ for example, the Court rejected the prior broad aggregation test for Congress' Commerce Clause power in favor of a much stricter, particularized "substantial effects" test. The Court then found that the specific subject of the law at issue-regulating gun trafficking in a school-zone-did not have a substantial affect on interstate commerce, and it therefore found the law an unconstitutional exercise of congressional authority.

These cases and others signal sharply diminished congressional power under the Commerce Clause to address national problems of discrimination and violence. They thereby indirectly, but importantly, contribute to the hastening demise of civil rights enforcement in America. Indeed, observers worry that the next Commerce Clause attack will invalidate individual discrimination claims under the important Public Accommodations section (Title II) of the 1964 Civil Rights Act. A pending case, United States $v$. Nelson, ${ }^{141}$ is already challenging 'Congress' authority under the Commerce Clause to enact criminal civil rights laws. This challenge, says one commentator, "very directly threatens the heart of civil rights protections in America. If [the law] were held to be an unconstitutional exercise of congressional power in light of this new reading of the commerce clause, then the federal government will have lost one of its principal remedies to protect civil rights." 142

138 Id. at 1755-59.

139 See Catharine A. MacKinnon, Disputing Male Sovereignty: On United States $v$. Morrison, 114 HARV. L. REV. 135 (2000) (discussing Morrison and noting that the Court's application of its new federalism defined states' responsibility to protect individuals' right to equal protection narrowly and, further, prevented federal legislation to protect equality rights in an area that the states have inadequately protected).

110514 U.S. 549 (1995). But see Heart of Atlanta Motel, Inc. v. United States, 379 U.S. 241 (1964) (holding that a federal civil remedy for private discrimination in public accommodations was a constitutional exercise of Commerce Clause authority because of its aggregate effect on interstate commerce).

${ }_{141}$ No. 98-1437 (2d Cir. 2000) (appeal pending).

1+2 Jeffrey Ghannam, Seroing $U_{p}$ Civil Rights, 87 ABA J., Feb. 2001, at 48 (quoting Martin Karlinsky, chair, Anti-Defamation League). 


\section{Multiracial ReSistance AND ReCONSTRUCTION}

The attack on civil rights may very well intensify. Theodore Olsen, the new Solicitor General who represented President Bush in the election case as a private attorney, has led the anticivil rights attack in recent years. Additionally, with the backing of conservative think tanks and scholars, Robert Bork and Abigail Thermstrom, he headed the offensive in the Supreme Court's Rice v. Cayetano case that now jeopardizes all Native Hawaiian programs, including the very Hawaiian Homelands program mentioned at the outset of this article. ${ }^{143}$ And, Attorney General Ashcroft's strident anti-civil rights record speaks for itself. ${ }^{144}$

So what is to be done? How are communities from different places concerned about genuine equality and justice, often separated by boundaries of race, culture and national origin, to stem the conservative attack on civil rights and to rejuvenate the Second Reconstruction? There are many possible responses. We address two. The first concerns collective process: How do progressives build the multiracial, cross-boundary alliances needed to not only stem the attack but also reconstruct the Reconstruction? The second concerns substance: As part of that revitalization, what do we collectively fight for?

\section{A. Multiracial Alliances}

One essential part of resistance and reconstruction lies in

143 See Bruce Dunford, State-funded Programs Benefitting Native Hawaiians Challenged, PR NEWSWIRE, Feb. 15, 2001, available in 2000 WL APWIRES; Dunford, Olsen As Solicitor General Could Impact Hawaiians, PR NEWSWIRE, available in 2001 WL APWIRES.

14 A staunch opponent of gun control and abortion and proponent of the death penalty, most recently Ashcroft led a partisan attack in the Missouri Senate last year against the confirmation of a prominent, moderate African American jurist to the federal bench. See John Solomon, Democrats Target Ashcroft Views on Race, Civil Rights, REC. N. N.J., Dec. 28, 2000, at A1. Describing his voting record during his term in the United States Senate as "abysmal" and questioning whether he would carry out his function as top law enforcement officer of the nation's civil rights laws, a broad coalition of civil rights groups opposed his nomination to the post of Attorney General. Lawyers Committee for Civil Rights Under Law Urges Rejection of John D. Ashcroft as Attorney General of the United States, Jan. 22, 2001 available in 2001 WL 4139263; Leadership Conference on Civil Rights Views as 'Deeply Troubling' Ashcroft Nomination to be Attorney General of the United States, PR NEWswIRE, Dec. 22, 2000, at 15:19:00, available in WL APRWIRES. 
the challenging task of forging lasting cross-boundary alliances. It is those larger progressive coalitions, with a critical edge, that can do the heavy intellectual and frontline activist work in the courts, legislatures, city halls, schools, and churches. Given the probability of the next twenty-year conservative federal judiciary, without these alliances, the efforts to dismantle civil rights will not only persist, they will prevail.

How do progressives forge these civil rights alliances? We described the task as "challenging." "Daunting" may be more appropriate. Today, we see two colliding impulses in our communities. One impulse is the desire of groups to build cross-boundary, and particularly interracial, alliances. The other impulse, amid demographic shifts, is to distrust "others," to doubt their motivations and question their actions.

How then are diverse communities to deal with this complex, dissonant reality - a movement toward needed intergroup alliances characterized partially by anger and distrust? As framed, the question is one that many of us prefer to avoid. It airs dirty laundry, offering no clear, affirming answers. Nevertheless, the question is one we must answer in order to build effective alliances - those that do not splinter under fire because of internal dissension. To deal forthrightly with the dissonant impulses, we need to develop sharper ways to handle the deep group-on-group grievances that underlie many superficial face-to-face dealings.

This means, first, we must assess common goals and interests - such as resisting each attack on civil rights, whether or not "our group" is directly targeted. Recall Sandoval. Though specifically about newcomers, Sandoval affects all concerned about civil rights enforcement. This also means we must grapple with what we see and hear but do not often discuss. Amid changing demographics, groups desiring to work together sometimes are stymied by deep group-to-group (often past but lingering) grievances held against one another. Often we are not even aware of the wounds. Yet it is group grievances, real and perceived, that often get in the way of forging effective alliances.

The question then is not so much "Can we all get along?," but rather "How do we all get along?" To ground this question, let us turn to Seattle and a fragile coalitional effort in support of civil rights. In July 1999, 6,000 journalists of color congregated in Seattle. Four journalist associations-African American, Hispanic, Native American and Asian American-met to 
deal with the media's reporting on civil rights and its role in shaping race issues. They also sought to forge larger industry alliances among themselves and with progressive Whites and environmentalists to counteract discrimination and racial stereotyping in the media.

Despite general agreement about disproportionate White control over the media and despite many cooperative efforts, simmering grievances among the associations threatened to turn disagreements about specifics-how to respond to Washington's anti-affirmative action initiative - into intergroup fires. The escalating sense of mistrust ("Are they just out for themselves?") and grievance ("They've taken advantage of us before") threatened their larger effort to collectively shape the tenor of race and civil rights understandings in America-all before the conference even began. 145

So the question becomes, "How do our progressive communities build relationships, reconciling grievances where needed, in order to live together peaceably and work together politically?" And here, the "communities" we refer to are not only defined by race. They are also defined by national origin, class, gender, sexual orientation and disability-the many communities disadvantaged by the broad-scale attacks on civil rights described earlier. ${ }^{146}$ Even more specifically, then, the question is, "How do we develop the concepts, language and methods our differing communities need both to identify common interests and to deal with intergroup grievances in ways that build effective political relationships?" Indeed, how could 6,000 journalists, attempting to coalesce and powerfully shape public civil rights understandings in America, themselves avoid fracturing along the subsurface fault lines of race, culture and national origin? Professor Yamamoto was asked at that gathering to speak with some of the journalists about these very questions. The response from many was compelling. We want to get together. We need to get together. "How," they asked, "do we do this"?

One suggestion we offer is that progressives, collectively, focus both "out there" and "in here." The "out there" focus is

145 See Eric K. Yamamoto, Sympositm: The First National Meeting of the Regional People of Color Legal Scholarship Conferences: Celebrating Our Emerging Voices: People of Color Speak: Healing Our Own, 20 B. C. THIRD WORLD L.J. 101 (2000).

146 See, e.g., Danielle Kie Hart, Same-Sex Marriage Revisited: Taking a Critical Look at Baehr v. Lewin, 9 Geo. MASON U. CIV. RTS. L.J. 1 (1998); Trina Grillo \& Stephanie M. Wildman, Obscuring the Importance of Race: The Implications of Making Comparisons Between Racism and Sexism (Or Other -Isms), 1991 DUKE L.J. 397 (1991). 
one of the ways that economic power, politics and social perception shape the "racial order" in any given locale and in American society generally. ${ }^{147}$ The focus "out there" thus jointly analyzes the systematic attacks on civil rights, as reflected in Sandoval. It searches out common interest in struggling against these ongoing attacks and thereby offers a target of collective resistance. But that is not enough.

The focus "in here" needs to be on mutual understanding of sometimes similar, sometimes differing group histories of struggle against discrimination as well as current racial conditions. It is also a focus on understanding group cultural practices. It is a focus on addressing and, where needed, healing, real and perceived intergroup wounds that get in the way of building alliances. It is thus a focus on the difficult dynamics of relationship-building among diverse groups harmed by racism and struggling to remake a fundamentally skewed social order.

In other works, Professor Yamamoto calls this aspect of the alliance-forging process interracial justice. ${ }^{148}$ For this brief exploration, we will not describe here how this concept draws from disciplines of law, theology, social psychology, ethics, political science, and indigenous group communal healing practices. Nor will we explain the methodological frameworka framework marked practically by four Rs: Recognition, Responsibility, Reconstruction and Reparation. ${ }^{149}$

We do, however, emphasize the significance and difficulty of intergroup efforts to cross-boundaries, sight common goals, deal with internal grievances and build relationships - all with an eye toward forming the deep and effective alliances needed to stem the attacks on civil rights and rejuvenate the Second Reconstruction.

\section{B. Redefining Discrimination}

Resistance and reconstruction engage both process and substance. What we are fighting for is to reinvigorate the spirit of the Reconstruction and to end discrimination in all its forms.

147 See CLAIRE KIM, BITTER FRUIT (2000) (describing the generation and maintenance of a "racial order" in the U.S.). We are using the term "racial order" here as shorthand for social structural ordering that also encompasses intersecting influences of gender, class, national origin, sexual orientation and disability.

148 See, e.8., ERIC K. YAMAMOTO, INTERRACIAL JUSTICE: CONFLICT AND RECONCILIATION IN POST-CIVIL RIGHTS AMERICA 10-11 (1999) (describing the framework of inquiry).

1s See id. (describing the framework of inquiry). 
Many substantive efforts are needed. Paramount among them is the redefinition of unlawful discrimination. ${ }^{150}$ With one important exception, the law defines discrimination as an individual actor's intentional differential treatment of those similarly situated. ${ }^{151}$ However, that definition, with its "intent" component, does not accurately reflect how discrimination actually occurs in many instances. The one exception to this restrictive legal definition is found in section 602 of Title VI. Section 602 , as earlier interpreted by the Supreme Court, allows federal agencies to promulgate regulations to prohibit acts by federal contractors that have "disparate impacts" on the basis of race or national origin. ${ }^{152}$ No proof of discriminatory intent is required to state a section 602 claim for injunctive relief. 153

The State of Alabama in Sandoval now seeks to abolish this one remaining "exceptional" understanding of discrimination. Sandoval speaks to the heart of civil rights law-how discrimination actually occurs.

1. The attempt to abolish a private right of action to enforce agency disparate impact regulations under section 602 of Title VI in context.

The agency regulations under section 602 of Title VI, providing a federal private right of action for disparate impact discrimination claims, are the last legal refuge for private redress of institutionalized forms of discrimination. As previously discussed, judicial acceptance of direct challenges to federal civil rights legislation, such as Title VII, section 601 of Title VI, and constitutional challenges to protective legislation enacted under the Equal Protection Clause have undermined effective enforcement of anti-discrimination laws. By "harmonizing" Title VII and section 601 of Title VI with the Court's Equal Protection Clause jurisprudence to require a showing of "intent" to discriminate, the Court has sharply retracted the civil rights gains of the Second Reconstruction. Indirectly, the Court's "new federalism" - strengthening the doctrine of state sover-

150 Another important substantive issue for civil rights in the new decade is conceptualizing and acting upon "reparations as a civil right." See RANDALL ROBINSON, AMERICA's DEBT 201-234 (1999); Eric K. Yamamoto, Racial Reparations: Japanese American Redress and African American Claims, 40 B.C. L. REV. 477 (1998).

151 See, e.g., McCleskey v. Kemp, 107 S. Ct. 1756 (1987).

152 Guardians Ass'n v. Civil Serv, Comm'n of New York City, 463 U.S. 582, 593 (1983).

153 See id. 
eign immunity and, correlatively, restricting Congress' authority under the Commerce Clause and enforcement powers under Section Five of the Fourteenth Amendment-has chipped away states' accountability to both the federal government and private individuals.

Taken together, these direct and indirect challenges signify a pivotal retreat from the promises of the Second Reconstruction. In this context, section 602 of Title VI is crucial; it represents the last remaining harbor for enforcing agency disparate impact regulations. As discussed below, if the Court bars private rights of action and applies its strict Equal Protection "intent" requirement to claims brought under section 602, neither the individual victims nor federal agencies will be able to challenge federally-subsidized disparate impact discrimination.

2. Preserving a private right of action to enforce agency disparate impact regulations under section 602 of Title VI is critical because the "intent" standard fails to identify and redress how discrimination actually occurs.

A decision for the State of Alabama in Sandoval will eliminate every individual's right to challenge patterns of "disparate impact" discrimination under Title VI. As discussed above, disparate impact claims were integral to the hard-earned congressional and executive commitment to civil rights enforcement. ${ }^{154}$ That commitment to civil rights, however, has been largely undermined by successful challenges to both federal legislation and constitutional protections. In Washington $v$. Davis the Supreme Court eliminated legal redress for most institutionalized discrimination by requiring a showing of actual "intent." 155 In Bakke, the Court imported the strict Equal Protection intent standard to claims brought under section 601 of Title VI. 156 Then, in Wards Cove, the Supreme Court severely undermined the principle of disparate impact under Title VII. ${ }^{157}$

At the same time, an elaborate network of sophisticated conservative organizations worked to undermine affirmative action, institute "English-only" laws and advance antiimmigration measures. What was once an aggressive legal commitment to civil rights enforcement has become in the eyes

15- See sitpra notes 72-74 and accompanying text.

155 See Washington v Davis, 426 U.S. 229, 242-44 (1976).

156 See Regents of the Univ. of Calif. v. Bakke, 438 U.S. 265, 289-91 (1978).

157 See Wards Cove Packing, Inc. v. Atonio, 490 U.S. 642, 656-58 (1989). 
of many subordinated Americans, another Broken Promise. And section 602 of Title VI - the last remnant of that commitment to civil rights that authorizes disparate impact civil rights enforcement - is now under attack.

The Supreme Court's ruling in Sandoval on disparate impact claims brought under section 602 of Title VI is therefore crucial. If the Court imposes the strict "intent" standard on claims brought under that section, the most pervasive forms of racism experienced by communities of color will go undetected because the intent standard fails to acknowledge that discrimination.

More specifically, the intent standard is ineffective to remedy continuing inequality and racial disparity because it fails to reflect how a large part of discrimination actually occurs. ${ }^{158}$ By treating racism as an isolated phenomenon resulting from the bias of a sole actor rather than as acially constructed and historically-influenced dynamic, the intent standard denies the historic reality of race in America. ${ }^{159}$ Indeed, as Professor Charles R. Lawrence III queried:

Does the black child in a segregated school experience less stigma and humiliation because the local school board did not consciously set out to harm her? Are blacks less prisoners of the ghetto because the decision that excludes them from an allwhite neighborhood was made with property values and not race in mind? 160

By requiring a specific showing of intent, the court has placed many forms of racism beyond legal redress.

Substantial empirical and theoretical research in the fields of social psychology, cognitive psychology, and organizational sociology has demonstrated that much of society's racism is not a series of unconnected, intentional acts, but a collective and often subconscious institutional and historical process. ${ }^{161}$ According to this vast body of empirical and theoretical research, "intent" - previously viewed as connected only to blatant or calculated acts - is linked to institutional structures, subconscious categorization, and information processing. ${ }^{162}$

158 Krieger, sitpra note 90, at 1181; see also Lawrence, infra note 160, at 319.

159 BELL, supra note 26, at 136-44.

160 Charles R. Lawrence III, The Id, The Ego, and Equal Protection: Reckoning with Unconscious Racism, 39 STAN. L. REV. 317, 319 (1987).

161 Krieger, supra note 90, at 1187-88.

162 Id. at 1188, 1216 (citing, inter alia, David L. Hamilton, A Cognitive-Attributional Analysis of Stereotyping, in 12 ADVANCES IN EXPERIMENTAL SOCIAL PSYCHOLOGY 2, 53, 


\section{Motivation \\ a. Social Cognition and Subconscious Discriminatory}

Studies in social cognition reveal that humans rely on categorization as a basic tool for interpreting perceptions, encoding those perceptions into memory, and making both conscious and subconscious decisions based on those perceptions and memories. ${ }^{163}$ " $[\mathrm{T}]$ he normal human mind cannot possibly notice, let alone analyze and use, every bit of social information it encounters." 164 Because the amount of potential information is overwhelming, adult minds become exceptionally able to screen, sort, and store information. 165

Individuals ordinarily process information very quickly and efficiently through shortcuts or "cognitive strategies." 166 "Dividing up the social world into categories is an example of a cognitive strategy."167 Because of this efficiency, individuals are "generally unaware of their own mental processes and are unable to report the true reasons for their behavior." 168

In particular, "stereotyping" is a cognitive strategy that allows the mind to interpret information very quickly. ${ }^{169}$ It is a normal and ordinary form of categorizing engaged in by all people as part of the sorting and organization needed to manage large quantities of information. ${ }^{170}$ As Professor Krieger explains, individuals give substance to a stereotype by creating a prototype of the typical category member based on "a person's accumulated knowledge, beliefs, experiences ... and expectancies."171 This culturally-generated prototype, or "social

64 (Leonard Berkowitz ed., 1979)); John A. Barth, Conditional Automaticity: Varieties of Automatic Influence in Social Perception and Cognition, in UNINTENDED THOUGHT 3 (James S. Uleman \& John A Bargh eds., 1989)); see also Lawrence, supra note 160.

163 Krieger, supra note 90, at 1187-90 (citing Eleanor Rosch, Human Categorization, in Studies in Cross-Cultural PsyChology 1, 1-2 (Neil Warren ed., 1977); David E. Rumelhart, Schemata and the Cognitive System, in 1 HANDBOOK OF SOCIAL COGNITION 167 (Robert S. Wyer, Jr. \& Thomas K. Srull eds., 1984)).

164 Judith Olans Brown et al., Some Thoughts About Social Perception and Employment Discrimination Law: A Modest Proposal for Reopening the Judicial Dialogue, 46 EMORY L.J. 1487, 1494 (1997).

165 Id.

166 Id. (citing SUSAN T. FISKE \& SHELley E. TAYLOR, SOCIAL COGNITION 11 (1984)).

167 Id; see also Krieger, supra note 90, at 1187-88.

168 Brown, supra note 164, at 1494 (citing Richard E. Nisbett \& Timothy DeCamp Wilson, Telling More Than We Can Know: Verbal Reports on Mental Processes, 84 PSYCHOL. REV. 231, 231-59 (1977)).

tof Krieger, supra note 90 , at 1188-90.

170 Id. at 1187-88 (citing W. Edgar Vinacke, Stereotypes As Social Concepts, $45 \mathrm{~J}$. SOC. PSYCHOL. 229, 241 (1957)).

171 Id at 1199; see also ERIC K. YAMAMOTO, INTERRACIAL JUSTICE: CONFLICT AND 
schema," operates as a filter that biases "in predictable ways the perception, interpretation, encoding, retention, and recall of information about other people." 172

As a result of this stereotyping process, people perceive members of outgroups to be different from those in the ingroup, or an "undifferentiated mass." 173 Generally, an individual subconsciously assigns favorable traits to his or her own group and disfavorable traits to outgroups or "others." 174 In addition, people recall negative behavior of outgroup members and tend to favor ingroup members in the allocation of rewards. ${ }^{175}$ Information that does not correspond with the mental prototype is subconsciously rearranged or reorganized according to systemic biases, resulting in judgments that tend to favor those seen as ingroup members and disfavor outgroup members even in the absence of blatant prejudice, ill-will or animus. ${ }^{176}$

This filtering process is cognitive and is therefore part of the actor's motivation for acting. Yet, the filters operate even without specific intent to favor members of a particular social group at the "moment of decision." 177 As Professor Krieger has explained, these filters bias a decisionmaker's judgment long before that decisional moment, and most importantly, they often operate beyond the reach of decisionmaker self-awareness hence, the subconscious discriminatory motivation.

RECONCILIATION IN POST-CIVIl RIGHTS AMERICA 90-97 (1999) (attributing that substance-giving largely to culture).

172 Krieger, supra note 90, at 1188, 1200 (citing Shelley E. Taylor \& Jennifer Crocker, Schematic Bases of Social Information, in 1 SOC. COGNITION 89 (E. Tory Higgins et al. eds., 1981)).

For example, when meeting someone for the first time, individuals rely on categories and distinctions already at their disposal, rather than actively formulating new ones. Once individuals perceive that the person they are meeting belongs to a specific social group, their reactions may be dominated by this single characteristic; and they may fail to notice other important facts about the person.

Brown, supra note 164, at 1495 (citing Ellen J. Langer, THE PSYCHOLOGY OF CONTROL 135-36 (1983).

173 Krieger, supra note 90, at 1192 (citing Edward E. Jones, George C. Wood \& George A. Quattrone, Perceived Variability of Personal Characteristics in In-Groups and Out-Groups: The Role of Knowledge and Evaluation, 7 PERSONALITY \& SOC. PSYCHOL. BULL. 523, 523-24 (1981) (other citations omitted)).

174 See Brown, supra note 164, at 1494 (citing JOHN C. TURNER, SOCIAL. IDENTITY AND INTERGROUP RELATIONS 17, 30 (Henri Tajfel ed., 1982)).

175 Krieger, supra note 90, at 1191-1192 (citing John W. Howard \& Myron Rothbart, Social Categorization and Memory for In-Group and Out-Group Behavior, $38 \mathrm{~J}$. PERSONALITY \& SOC. PSYCHOL. 301, 302-03 (1980)).

176 Krieger, supra note 90, at 1191-92, 1216.

$177^{\circ}$ ld. at 1188. 
In essence, "people continually use cognitive shortcutsexaggerations, oversimplifications, generalizations - to allow them to prioritize and, in some gross way, make sense of the overload of incoming information." 178 Racial stereotyping is one method that people employ almost automatically in order to understand their surroundings. As social cognition studies reveal, even individuals who recognize that racial stereotyping is unsound are still aware of - and still influenced by - those stereotypes. There is little likelihood, therefore, that in a complex institution all or even most of the various individuals with input into decision-making processes will manage to eliminate from their perceptions, memory processes and ultimate decisions the influence of deeply-ingrained cultural and institutional stereotypes.

\section{b. Organizational Sociology and "Institutionally-Intended} Discrimination."

Organizational sociology and institutional racism theory similarly have concluded that discrimination, a form of oppression, can be built into institutional structures. ${ }^{179}$ Actors within these structures deliberately act according to established institutional norms and practices that sometimes reflect discriminatory beliefs. For example, not long ago, the practice of racial and gender exclusion in private clubs was justified by club members who "had nothing against Blacks or women" but who merely were upholding traditional club practices. More particularly, the discrimination that some groups suffer results not from the tyrannical acts of a dominant ruler but from the daily practices of a generally well-intentioned societydiscrimination "embedded in unquestioned norms, habits, and symbols, in the assumptions underlying institutional rules and the collective consequences of following those rules." 180 Even if individual actors believe they harbor no ill-will toward others, they may by their deliberate actions carry out the institution's discriminatory operations, which are rooted historically in discriminatory stereotypes. When those actors are also aware that carrying out an institutional practice may have racially discriminatory effects, they are acting with at least subconscious

178 Brown, supra note 164 , at 1496.

179 Ian F. Haney Lopez, Institutional Racism: Judicial Conduct and a New Theory of Racial Discrimination, 109 YALE L.J. 1717 (2000).

180 Iris Marion YoUnG, JUSTICE AND THE POLITICS Of DifferenCe 41 (1991). 
racially discriminatory motivation.

Institutional racism theory also "stresses how racial institutions ... operate as taken-for-granted understandings of the social context that actors must adopt to make sense of the world ..."181 As part of the institutional structure, "persons fail to recognize their reliance on racial notions, and indeed may stridently insist that no such reliance exists, even while acting in a manner that furthers racial status hierarchy."182 Organizational sociologists thus observe that discriminatory human behavior within institutions often does not occur at a high level of consciousness - that is, much of the behavior is not explicitly purposeful. ${ }^{183}$ It is, however, subconsciously purposeful in that it stems from the deliberate yet "unconsidered repetition of cognitively familiar routines." 184 In other words, "we often act in definable ways without a consciously formulated purpose," because the institution's practices and norms tell us that this "is 'the way it is done," and how it is done comports with our subconscious beliefs. ${ }^{185}$

Cognitive and social psychology and organizational sociology confirm that the intent standard is inadequate to remedy the true conditions of inequality experienced by those most subordinated because it does not reflect how a large part of discrimination actually occurs. By treating racism as isolated and intentional rather than institutionalized and historical, the intent standard denies the reality of race in America. This is a primary reason why section 602 of Title VI is vital.

\section{CONCLUSION}

Alexander $v$. Sandoval is significant because it embodies Alabama's effort to knock out a critical part of the civil rights edifice of the Second Reconstruction-individual victims' right to

181 Ian F. Haney-Lopez, supra note 179, at 1827.

182 Id.

183 Id. at 1723.

184 Id. (citing Peter L. Berger \& Thomas LuckmanN, The Social Construction OF REALITY: A TREATISE IN THE SOCIOLOGY OF KNOWLEDGE 54 (1966)). Research in "New Institutionalism" theory also demonstrates that routinized sequences of behavior eventually come to define normalcy, or more broadly, reality. Established constellations of action are seen but not noticed, relied upon but not considered, to such an extent that they become natural - 'the world of daily life known in common with others and with others taken for granted.'

Id. at 1723-24 (footnote omitted).

185 Id. at 1723. 
sue states and businesses receiving federal money for disparate impact discrimination. In a historical context, Sandoval is also significant because it signals another potentially pivotal retreat from America's commitment to civil rights for all, and particularly those suffering most from historic forms of discrimination. As this article has explained, over the past twenty years, piece by piece, a divided Supreme Court has dismantled civil rights. The United States is on the verge of a second broken civil rights promise - the dismantling of the Second Reconstruction of the 1950s and 1960s.

For those committed to genuine equality, we endorse a dual strategy of multiracial resistance (against that dismantling) and reconstruction (for revitalizing the Second Reconstruction). One part of that strategy is the challenging task of forging lasting cross-boundary alliances. It is those larger progressive coalitions, crossing lines of race, national origin, gender, sexual orientation and disability, with a critical edge, that can contribute to the heavy intellectual and frontline activist work in the courts, legislatures, city halls, schools and churches. As explored, those alliances are often fraught with tension. Progressives need to pay close attention to the dynamics of allianceforging, including identifying common goals, jointly analyzing social-economic-legal structures and tending to intergroup grievances.

A second part of the strategy of resistance and reconstruction is substantive. It entails reconceptualizing and rearticulating, persuasively, key components of the Second Reconstruction. One such component, discussed in this article, is retooling the law's understanding of how discrimination actually occurs in contemporary society. Discrimination now often assumes subtle forms, residing in facially neutral institutional practices and policies that are discriminatory in impact. This discrimination often occurs without evil-hearted individual actors but as a result of subconscious stereotyping and group-biased decisionmaking at multiple levels of institutional operations. New studies in cognitive psychology and institutional sociology confirm this fact. Crucial to revitalizing the Second Reconstruction is rebuilding legal definitions of discrimination to reflect this reality.

If the United States breaks its second civil rights promise, the societal cost will be steep-continuing inequalities and deepening social divisions. The soft rhetoric of colorblindness will not hide these hard realities. For this reason, we close this 
article with a call first to cross-boundary resistance to the dismantling of civil rights and then to revitalizing the Reconstruction for the betterment of all.

\section{CODA}

As this article was going to press, the Supreme Court rendered its decision in Sandoval. As anticipated, the Court eliminated a private right of action under Section 602 of Title VI. Alexander v. Sandoval, No. 99-1908, slip op. at 17 (April 24, 2001). The majority opinion, authored by Justice Scalia, precludes individuals from suing to enforce federal agency discriminatory impact regulations. As developed in the article, this ruling hastens the judicial dismantling of civil rights in America and intensifies the call for multiracial resistance and reconstruction. 
